\title{
A SYSTEMATIC REVIEW OF 3PLS' ENTRY INTO REVERSE LOGISTICS
}

\author{
L.L. Tombido ${ }^{1 \#}$, L. Louw ${ }^{1} \&$ J. van Eeden ${ }^{1 *}$
}

\section{ARTICLE INFO}

Article details

Presented at the $29^{\text {th }}$ annual conference of the Southern African Institute for Industrial Engineering (SAIIE), held from 24-26 October 2018 in Stellenbosch, South Africa

Available online

9 Nov 2018

Contact details

Corresponding author jveeden@sun.ac.za

Author affiliations

1 Department of Industrial Engineering, University of Stellenbosch, South Africa

\# The author was enrolled for a D Phil (Industrial Engineering) degree in the Department of Industrial Engineering, University of Stellenbosch, South Africa

\section{DOI}

http://dx.doi.org/10.7166/29-3-2062

\section{ABSTRACT}

The concepts of Industry 4.0 and closed loop supply chains are becoming popular as logistics management evolves. Industry 4.0, through its instruments such as cloud manufacturing and the Internet of Things, has been known to improve operations management significantly. At the same time, closed loop supply chains have gained momentum with the increase in environmental sustainability issues. However, closed loop supply chains are often associated with uncertainties in the timing, quality, and quantity of returns. For these and other reasons, most organisations employ third parties to perform most reverse logistics activities. This paper systematically reviews the literature on the entry and use of third parties in reverse logistics with the objective of providing researchers with future research directions for this fast-emerging topic. The results show that there is a need to expand on the literature and on managerial issues such as performance measurement of reverse logistics networks with third parties. The literature also needs to consider how third parties use technological aspects such as Industry 4.0 to manage and operate reverse supply chains successfully.

\section{OPSOMMING}

Die konsepte van industrie 4.0 en geslote voorsieningskettings word al hoe meer gewild soos logistieke bestuur ontwikkel. Dit is bekend dat Industrie 4.0, deur middel van instrumente soos wolkvervaardiging en die Internet van Dinge, bedryfsbestuur beduidend kan verbeter. Terselfdertyd het geslote voorsieningskettings momentum gekry met die toename in omgewingsvolhoubaarheidskwessies. Geslote voorsieningskettings word egter dikwels geassosieer met onsekerhede in die tydsberekening, kwaliteit en hoeveelheid opbrengste. Om hierdie en ander redes gebruik die meeste organisasies derde partye om die meeste omgekeerde logistieke aktiwiteite uit te voer. In hierdie artikel word die literatuur oor die toetrede en gebruik van derde partye in omgekeerde logistiek hersien, met die doel om navorsers toekomstige navorsingsaanwysings vir hierdie vinnig opkomende onderwerp te verskaf. Die resultate toon dat daar behoefte is aan die uitbreiding van die literatuur en bestuursvraagstukke soos prestasiemeting van omgekeerde logistieke netwerke met derde partye. Die literatuur moet ook oorweeg hoe derde partye tegnologiese aspekte soos Industrie 4.0 gebruik om voorsieningskettings suksesvol te bestuur en te bedryf.

\section{INTRODUCTION}

The forward chain includes activities such as purchasing raw materials from suppliers, producing serviceable products, and distributing them to various players until they reach the end customer. Nowadays, the forward chain is being extended by the reverse supply chain. The concept of reverse logistics is not entirely new: Robinson [1] stated that reverse logistics started as early as the 
American civil war. The same author also explained that customers had been returning products for various reasons before the term was even coined.

Le Blanc [2] listed the drivers of reverse logistics, such as legislation, economic factors, scarcity of resources, and market and asset protection, among others. Reverse logistics is concerned with the management of anything that goes in the opposite direction to the forward traditional supply chain in the form of returns. Disposition strategies in reverse logistics have been listed by Thierry, Salomon, Nunen, and Wassenhove [3] as re-use, refurbishing, remanufacturing, and recycling, among others.

As profitable as the reverse supply chain is, it requires expertise and some complicated technologies. As stated by Atasu [4], most forward chains are not designed to cater for the reverse flow; and this, in turn, affects the responsiveness of the supply chain. For example, Cisco has an almost monopolistic position in its core IT networking equipment business. However, it lags significantly in volume in the refurbishment equipment market, because refurbishing requires different capabilities that may not overlap well with the firm's forward chain.

Technologies such as Industry 4.0 are now being used for such complex supply chains. Industry 4.0 impacts the corporate world through digitalising both horizontal and vertical supply chains, products, services, business models, and customer relations. However, most established forward chains do not have adequate infrastructure to use such technologies and, for this reason, most organisations employ third party logistics providers (3PLs).

Aguezzoul [5] defined a 3PL provider as "A private firm that provides logistic services under a contract to a manufacturer, vendor or user of a product or service". It is called 'third party' because the logistics provider does not own the products, but participates in the supply chain at points between the manufacturer and the user of the end product. Craig [6] further emphasised that, even though 3PLs have moved to provide bundled services, they typically focus on providing a service rather than on being a means to outsource a service. Third party reverse logistics providers (3PRLPs) mostly focus on reverse logistic activities, and they enter the reverse logistics through the main activities of acquisition, reverse logistics, inspection, disposition, and distribution and sales. Because of their existence in the reverse supply chain, it is necessary to study the activities and processes that are required with the entry of $3 \mathrm{PLS}$ into reverse logistics.

There have been reviews in the field of reverse logistics. Ye and Zhenhua [7] reviewed the literature on reverse logistics published since 2000. They concluded that most of the studies focus only on small areas, and that there was a need to develop models for 3PLs involved in reverse logistics activities. Agrawal, Singh and Murtaza [8] claimed that research on reverse logistics focused specifically on issues to do with adoption, implementation, forecasting, product returns, outsourcing, and networks, and that not much attention has been given to disposition strategies in literature reviews. Methodologies used in analysing reverse logistics problems were reviewed by Rezaei [9], who focused specifically on the use of multi-criteria decision methods in reverse logistics. With the Journal of Cleaner Production becoming more popular in publishing articles on sustainability, Govindan, Soleimani and Kannan [10] performed a comprehensive review of recent and state-of-the-art papers to create frameworks for the past and future research directions on both reverse logistics and closed loop supply chains. Most reviews on reverse logistics are specific. Authors such as Guo, Shen, Choi and Jung [11] and Bazan, Jaber and Zanoni [12] reviewed the literature on supply chain contracts in reverse logistics and the literature on the modelling of reverse logistics inventory systems based on the economic order quantity (EOQ) respectively. In all these reviews, while 3PLs have been mentioned, together with some of the roles they play in reverse logistics, there has been no specific review actually to focus on published research on 3PLs in reverse logistics. In fact, no review has focused on the strategic, operational, and other decisions about third party reverse logistics providers (3PRLPs) and on how reverse supply chains are impacted by the presence of 3PLs.

The purpose of this review is to explore the literature on the use of 3PLs in reverse logistics, whether descriptive, quantitative, or empirical, and to identify research gaps at the end of the analysis. 3PLs join reverse supply chains as either hired parties or supply chain partners to collect used products, transport them, and reprocess or even redistribute them. Sometimes they just join such networks as links between supply chain partners by providing information technology infrastructure. The entry of 3PLs will impact the control structure of a supply chain, depending on how the activities are 
delegated in the supply chain. Involving 3PLs will also affect strategic decisions such as network design, production planning, and transport planning.

The rest of the paper is structured as follows: section 2 describes the systematic review methodology while applying it to the current topic; section 3 analyses the literature and identifies gaps according to how the literature is classified; and section 4 provides the conclusions and suggestions for future research.

\section{RESEARCH METHODOLOGY}

A systematic approach was used to perform the review. Denyer and Tranfield [13] defined a systematic review as "a specific methodology that locates existing studies, selects and evaluates contributions, analyses and synthesizes data and reports the evidence in such a way that allows reasonably clear conclusions to be reached about what is and what is not known". The systematic review followed five main stages, as listed by Denyer and Tranfield [13] and Thomé, Scavarda and Scavarda [14], and which are explained below.

Step 1: Planning and formulating the problem: In planning and formulating the problem, the first stage is to define the scope of the review in terms of its focus, goals, perspective, coverage, and organisation. The main focus of this comprehensive review is 3PLs being employed for any activity in reverse logistics. The goals of the review are to synthesise the literature, identify issues central to 3PLs entering reverse logistics, and suggest questions and research methods that should be addressed by future researchers in the field. The literature in the review will be arranged conceptually (according to related topics) and methodologically (according to the use of similar methods) where appropriate.

Question formulation is also part of planning research, as it is used in the identification of the research topic. Denyer and Tranfield [13] mentioned the 'CIMO' method of formulating research questions - that is, questions based on context, intervention, mechanisms, and outcomes. In this review, three questions were used to identify the research topic and scope:

1. What factors and activities lead to the entrance into reverse logistics by third parties (C)? How are 3PLs introduced into reverse logistics $(M)$ ? How does the entrance of third parties into reverse logistics impact supply chain performance, decisions, and operations (I)?

2. How has the literature on 3PRLPs evolved over the years? What was the central focus of the literature $(0)$ ?

3. Are there any aspects of 3PRLPs that make them different from other supply chain players, and how do they link Industry 4.0 to the reverse chain?

The review considered operations that are carried out when a company employs 3PRLPs, and decisions that have to be made in involving $3 \mathrm{PLS}$ in reverse logistics.

Step 2: Locating studies: This is the process of searching for articles on the subject from electronic databases, recommendations from known sources, or manually searching known journals. In this review, five tools for searching the literature were used.

1. The citation databases, Web of Science and Scopus. Thomé et al. [14] stated that "citation databases ensure a broader diversification of studies as they index journals and vendors databases all in one location". Scopus and Web of Science are two of the largest abstract and citation databases, which include over 20,000 peer-reviewed journals in the fields of science, technology, medicine, social sciences, and arts and humanities. These peer-reviewed journals belong to various publishing houses, including Elsevier, Emerald, Informs, Taylor and Francis, Springer, and Inder-Science. Some additional materials were obtained from Springer and Google Scholar. In the review, the literature was not restricted to specific journals.

2. Keyword search on an unrestricted timeline. Search results depended mainly on the use of the Boolean operators AND and OR. Three search statements were used: 'Outsourcing AND reverse logistics' OR '3PLs AND reverse logistics' OR 'Third party reverse logistics providers'. The search was conducted on 9 April 2018, and the initial search resulted in 196 papers. To incorporate industry 4.0 concepts, a search was also conducted with the statements 'Industry 4.0' AND 'Reverse logistics' OR 'Industry 4.0' AND 'Circular economy'. 
3. Review of selected abstracts to find articles that correctly meet the search criteria. For the sake of quality, the search was limited to journal articles, and excluded books and grey literature. Articles with 'in-press-corrected proof' status were also included. The initial search yielded 196 publications; to determine the relevance of each paper, abstracts and conclusions were read. Articles were excluded for only looking at 3PLs, but not in the context of reverse logistics; focusing on reverse logistics, but not on 3PRLPs; mentioning 3PRLPs only in passing and not focusing on them; and not being written in English.

4. Forward and backward searches. Forward searches were common mainly in articles obtained from Science Direct, as downloading one article was accompanied by a list of recommended articles and articles citing the same article. These recommendations were reviewed. Backward searches were conducted for every approved article from its list of references.

As a result of the exclusion criteria, 134 articles remained. Table 1 shows the distribution of databases for the articles used in the review, and Figure 1 shows the most common journals with articles on 3PRLPs.

Table 1: List of databases selected for the review

\begin{tabular}{llll}
\hline Database & Number of publications & Database & Number of publications \\
\hline Science Direct & 60 & JStor & 1 \\
\hline Emerald & 6 & Scientific.net & 7 \\
\hline Taylor and Francis & 16 & Scopus & 4 \\
\hline Springer & 17 & Sage & 1 \\
\hline InderScience & 6 & Palgrave & 1 \\
\hline Research gate & 7 & Ebscohost & 1 \\
\hline Wiley & 1 & Other sources (not mentioned) & 6 \\
\hline
\end{tabular}

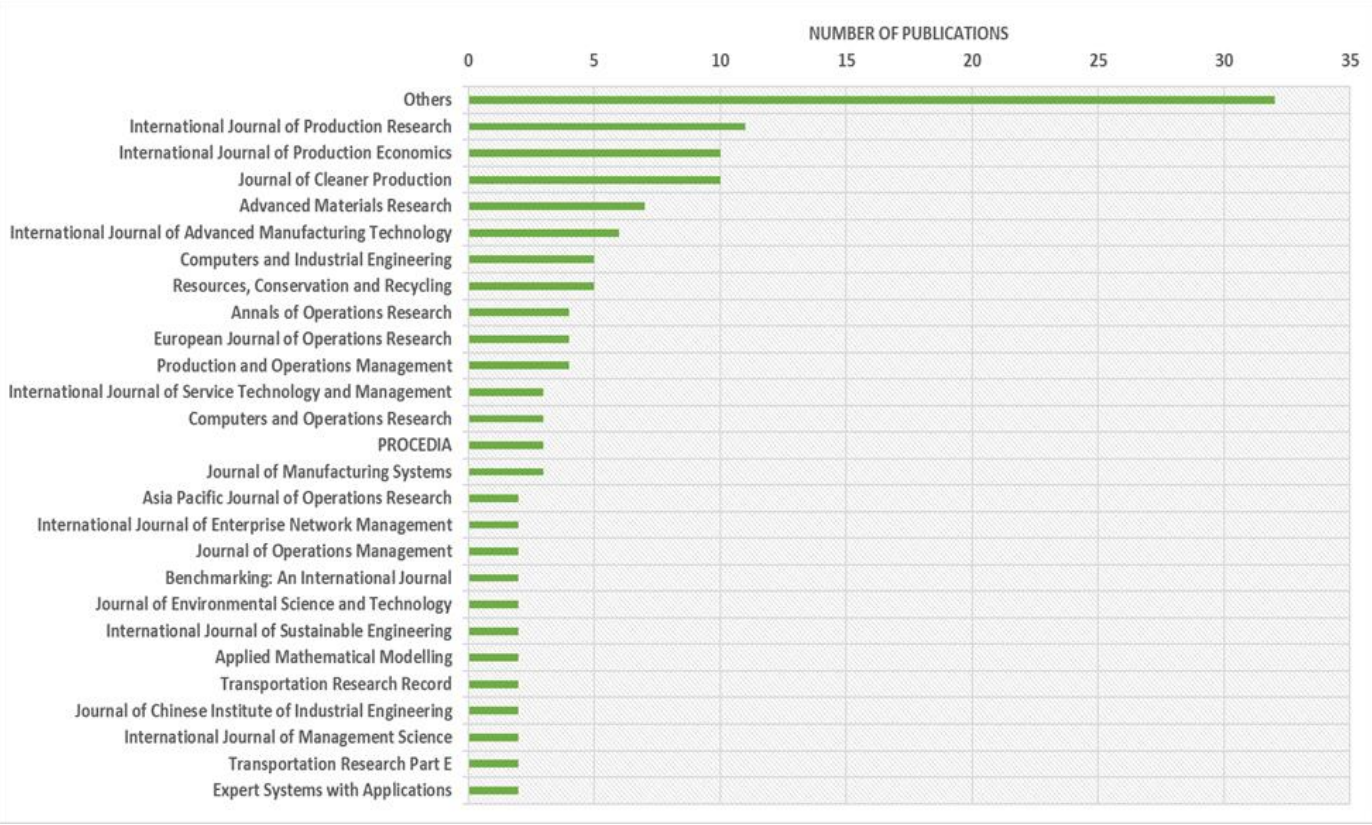

Figure 1: Most popular journals for selected publications

From Table 1, Science Direct is the most common database for most of the articles, and most articles from Science Direct are found in the International Journal of Production Economics and the Journal of Cleaner Production. Although the Taylor and Francis group do not have the majority of the articles on 3PRLPs, the International Journal of Production Research has the most publications on the topic. Figure 1 indicates that the majority of the articles are scattered among different journals in the databases.

Step 3: Analysis and synthesis: In this stage, individual studies are broken down into their constituent parts and their relationships to one another are established. All this is carried out and explained in the next sections. 
Step 4: Reporting and using the results: This section provides a summary of the review, limitations of the study, recommendations for policy and practice, and future research needs. Mostly the results of the research have a structure that includes an introduction, methodology, discussion, and conclusion.

Steps 1 and 2 of this research have already been explained; the next sections will describe the last two steps.

\section{LITERATURE ANALYSIS AND SYNTHESIS}

Figure 2 shows the research trends of the literature on 3PRLPs.

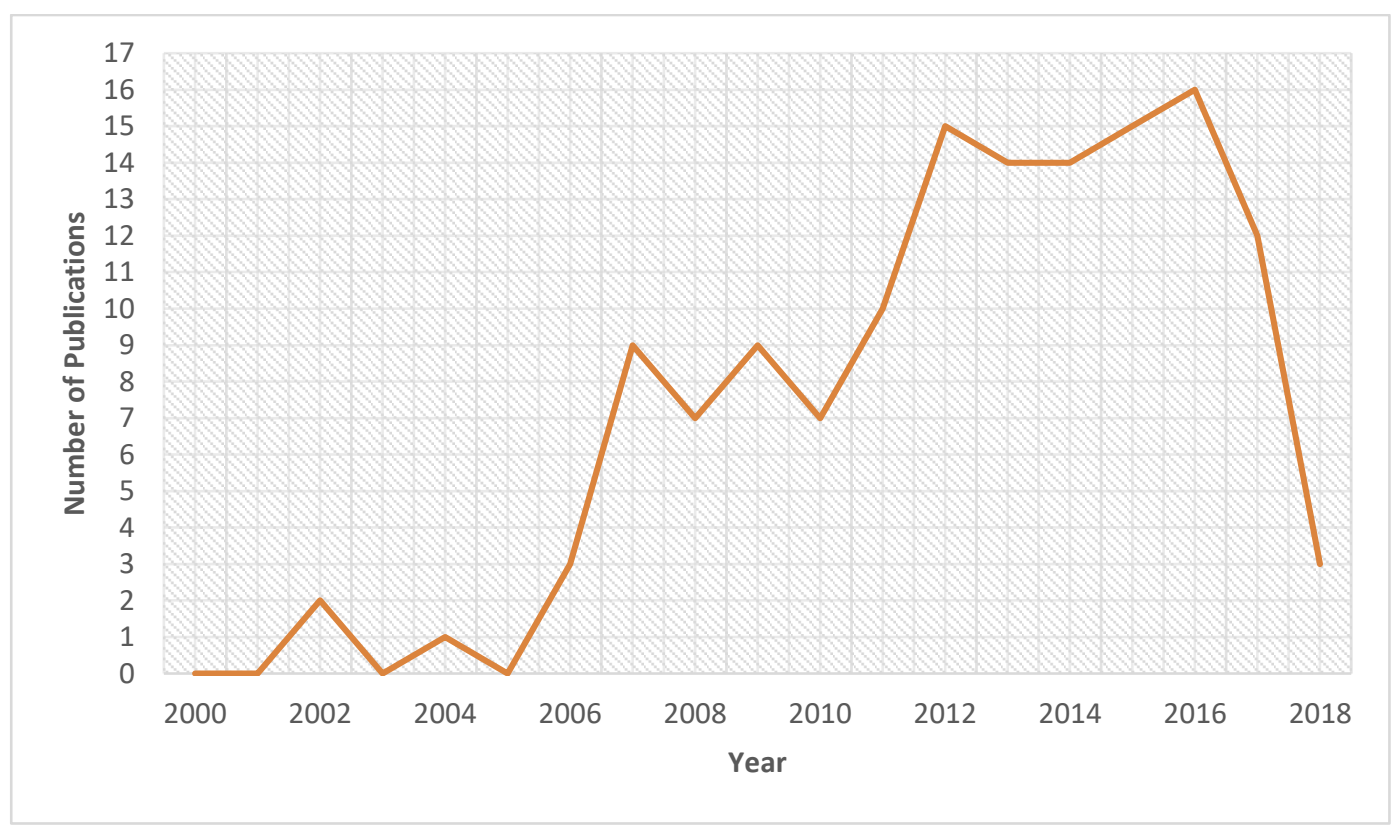

Figure 2: Research trends for the past 19 years

The general trend is an increase in the literature on 3PRLPs over the past 19 years. The sharp decrease in 2018 is because the review was carried out in the first quarter of that year. Some literature on 3PRLPs appeared in 2002, but it was not very common: only two papers were published that year. The topic gained popularity from 2006 onwards, when the number of publications began, and continued, to increase.

The literature was analysed in a thematic way. This involved grouping different publications according to a common topic. Table 2 explains the common themes, together with the number of publications for each theme, and Figure 3 represents this distribution using a pie chart.

As indicated in Table 2 and Figure 3, the majority of the literature focused on the evaluation and selection of 3PRLPs. The areas least looked into included performance measurement in reverse logistics channels with 3PRLPs, and production planning and inventory issues between original equipment manufacturers and the 3PRLPs.

The literature was further split into two decades. The period from the year 2000 to the year 2009 was classified as the first decade ('the past'), and the period from 2010 to 2018 represented the second decade (the 'state of the art') of research on 3PRLPs. Separating the literature into decades was necessary to show research directions for each theme, based on 'the past' and 'the state of the art'. Figure 4 shows a comparison of the first and second decades according to each research theme mentioned. 
Table 2: Classification of themes in 3PRLPs research

\begin{tabular}{|c|c|c|c|c|c|}
\hline Theme & Description & Publications & Theme & Description & Publications \\
\hline $\begin{array}{l}\text { 3PRLP } \\
\text { evaluation and } \\
\text { selection }\end{array}$ & $\begin{array}{l}\text { Selection of } \\
\text { 3PRLPs for } \\
\text { different reverse } \\
\text { logistics activities }\end{array}$ & 47 & $\begin{array}{l}\text { Closed loop } \\
\text { supply chain } \\
\text { effective } \\
\text { operating } \\
\text { mode }\end{array}$ & $\begin{array}{l}\text { Allocation of } \\
\text { responsibility for } \\
\text { reverse logistics } \\
\text { activities to } \\
\text { maximise profits } \\
\text { while minimising } \\
\text { costs, etc. }\end{array}$ & 25 \\
\hline $\begin{array}{l}\text { Influential } \\
\text { issues }\end{array}$ & $\begin{array}{l}\text { Issues that } \\
\text { influence a } \\
\text { decision about } \\
\text { employing 3PRLPs }\end{array}$ & 22 & Competition & $\begin{array}{l}\text { Competition } \\
\text { between } \\
\text { manufacturer and } \\
\text { independent 3PRLP } \\
\text { for cores and/or } \\
\text { markets }\end{array}$ & 6 \\
\hline $\begin{array}{l}\text { Network } \\
\text { design }\end{array}$ & $\begin{array}{l}\text { Location and } \\
\text { allocation of } \\
\text { facilities in a } \\
\text { reverse logistics } \\
\text { network with } \\
\text { 3PRLPs }\end{array}$ & 18 & $\begin{array}{l}\text { Performance } \\
\text { measurement }\end{array}$ & $\begin{array}{l}\text { Evaluating the } \\
\text { performance of a } \\
\text { reverse logistics } \\
\text { network with } \\
\text { 3PRLPs }\end{array}$ & 3 \\
\hline $\begin{array}{l}\text { Production } \\
\text { planning and } \\
\text { inventory } \\
\text { control }\end{array}$ & $\begin{array}{l}\text { Production } \\
\text { planning and } \\
\text { inventory issues } \\
\text { in a reverse } \\
\text { logistics network } \\
\text { with 3PRLPs }\end{array}$ & 3 & Other issues & $\begin{array}{l}\text { Issues about 3PRLPs } \\
\text { that do not fit in } \\
\text { any of the } \\
\text { mentioned themes }\end{array}$ & 5 \\
\hline Combinations & $\begin{array}{l}\text { Research } \\
\text { combining at } \\
\text { least two of the } \\
\text { mentioned } \\
\text { themes }\end{array}$ & 5 & & & \\
\hline
\end{tabular}

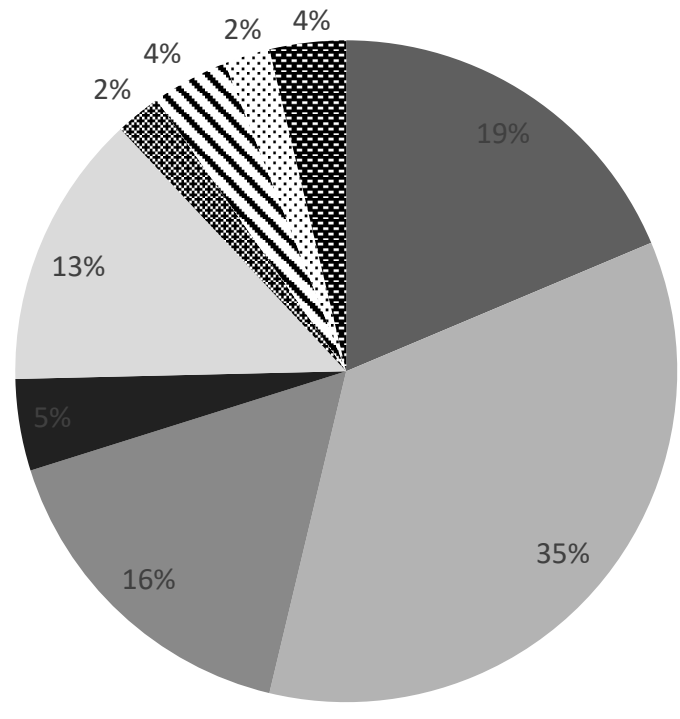

CLSC effective operating and collecting mode

- 3PRLP evaluation and selection

Influential issues

Competition

Network design

Performance measurement

Other issues

$\because$ Production planning and

inventory control issues

combination

Figure 3: Distribution of the literature among specific themes

The period from 2000 to 2009 did not only have few publications: it also had fewer research themes with regard to 3PRLPs. Themes such as performance measurement and other issues were introduced in the period from 2010 onwards, which shows how the issue of 3PRLPs has been evolving. The general trend is for an increase in publications for every research theme, although there are outliers in the themes of competition and production control. These two themes are also underexplored. 


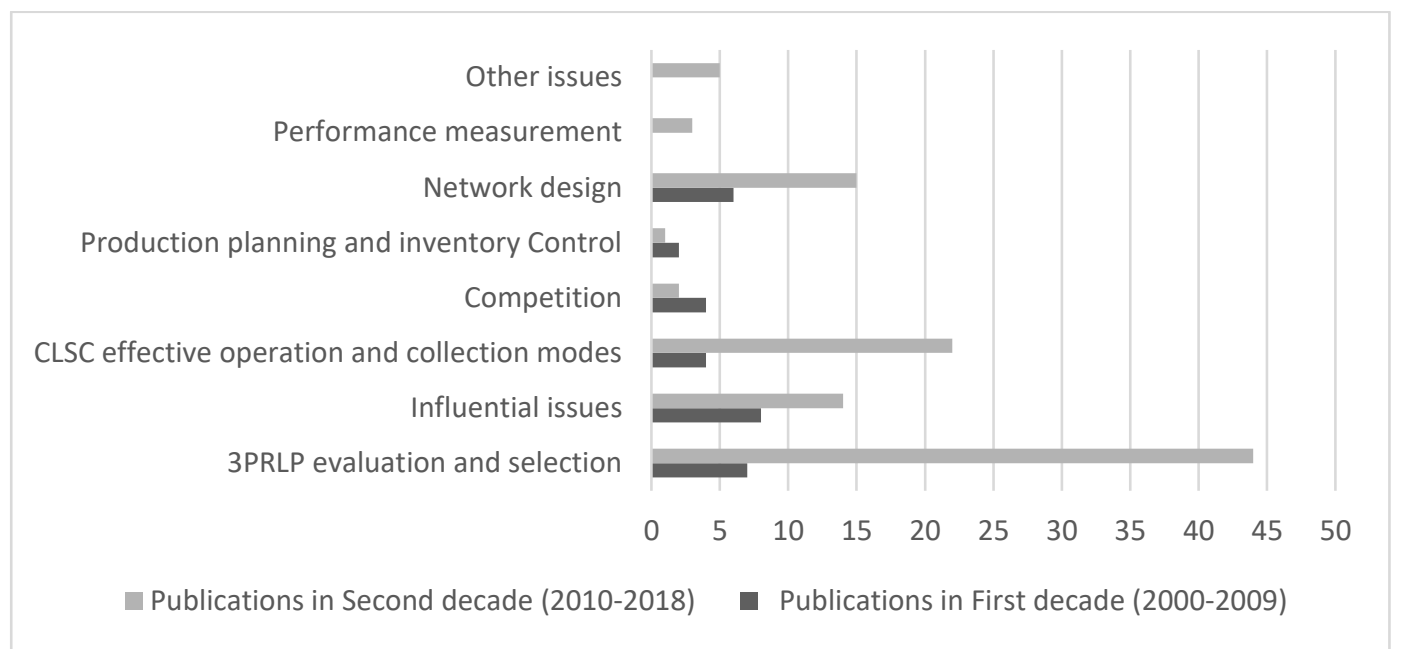

Figure 4: Distribution of the literature over the two decades

\subsection{PRLP evaluation and selection}

This has been the most explored topic in the past 19 years, constituting 35 per cent of the publications. Analysis of the category included a consideration of the methodologies used, the type of products mostly considered, and the reverse logistic activities for which the 3PRLPs were being selected, the disposition strategy considered, and whether real case studies were considered in the proposition of selection methodologies. Table 4 summarises the literature on the selection and evaluation of 3PRLPs.

The literature on the evaluation and selection of 3PRLPs has evolved from the use of one multicriteria decision-making method to the use of three methods all in one publication. This topic is still evolving in terms of methodology. Kafa, Hani and El Mhamedi [15] used AHP, TOPSIS, and PROMITHEE in evaluating and selecting 3PLs. The topic also has very popular authors. Most of the authors only vary their methodologies while using the same case studies in their research. The most popular authors on this topic throughout the years are listed in Table 3.

Table 3: Most popular authors on the evaluation and selection of 3PRLPs

\begin{tabular}{|c|c|c|c|c|c|}
\hline Author & Country & $\begin{array}{l}\text { Number } \\
\text { publications }\end{array}$ & Author & Country & $\begin{array}{l}\text { Number of } \\
\text { publications }\end{array}$ \\
\hline $\begin{array}{l}\text { Govindan } \\
\text { Kannan }\end{array}$ & Denmark & 7 & $\begin{array}{l}\text { Murugesan } \\
\text { Panaliappan }\end{array}$ & USA & 6 \\
\hline $\begin{array}{ll}\text { Saen } & \text { Farzipoor } \\
\text { Reza } & \\
\end{array}$ & Iran & 7 & Azadi Majid & Australia & 5 \\
\hline Tavana Madjid & USA & 3 & Kafa Nadine & France & 3 \\
\hline
\end{tabular}

In terms of reverse logistics activities, most 3PRLPs are selected to perform the collection and disposition operations, although some organisations outsource all of the reverse logistics activities - as illustrated by Sabtu, Saibani, Ramli and Ab Rahman [16]; Venkatesh, Bhattacharya, Sethi and Dua [17]; Tavana, Zareinejad, Artega, Kaviani, and Amin [18] ; Mavi, Goh, and Zarbakhshnia [19]; and Zarbakhshnia, Soleimani, and Ghaderi [20]. The most common disposition methods investigated are remanufacturing, recycling, and re-use. Repair and refurbishing still need more literature. In terms of disposition and reverse logistics, it will also be more interesting to find the literature that combines reverse logistics activities and disposition methods, depending on the 3PLs' ability -.as in, for example, the research carried out by Prakash and Barua [21], where they combined the disposition methods of re-use, recycle, repair, and remanufacturing while the 3PRLP performed collection and inspection. 
Table 4: Summary of the literature on evaluation and selection of 3PRLPs

\begin{tabular}{|c|c|c|c|c|c|}
\hline Author & Year & Method & $\begin{array}{l}\text { Product under } \\
\text { study }\end{array}$ & Disposition method & 3PRLP main focus \\
\hline [22] & 2002 & ANP & Not specified & Not specified & Not specified \\
\hline [23] & 2008 & AHP, neural networks & Not specified & Not specified & Not specified \\
\hline [24] & 2009 & ISM, TOPSIS & Batteries & Re-use, recycling & $\begin{array}{l}\text { Collection, inspection, } \\
\text { transportation }\end{array}$ \\
\hline [25] & 2009 & AHP & Batteries & Not specified & Collection, inspection \\
\hline [26] & 2009 & TOPSIS & Not specified & Not specified & transportation \\
\hline [27] & 2009 & AHP, linear programming & Not specified & Not specified & Not specified \\
\hline [28] & 2009 & DEA & Not specified & Not specified & Not specified \\
\hline [29] & 2010 & AHP & Not specified & Not specified & Not specified \\
\hline [30] & 2010 & DEA & Not specified & Not specified & Not specified \\
\hline [31] & 2010 & ANP & LCDs & $\begin{array}{l}\text { Remanufacturing, } \\
\text { repackaging, refurbishing }\end{array}$ & Collection, disposal \\
\hline [32] & 2011 & Fuzzy extent analysis & batteries & Not specified & Not specified \\
\hline [33] & 2011 & DEA & Not specified & Not specified & Not specified \\
\hline [34] & 2011 & DEA & Not specified & Not specified & Not specified \\
\hline [35] & 2011 & DEA & Not specified & Not specified & Not specified \\
\hline [36] & 2011 & AHP, TOPSIS & computers & Not specified & Not specified \\
\hline [37] & 2011 & AHP, PROMITHEE & Home appliances & recycling & Disposition \\
\hline [38] & 2012 & DEA & Not specified & Not specified & Not specified \\
\hline [39] & 2012 & ISM & tires & recycling & Collection \\
\hline [40] & 2012 & $\mathrm{AHP}$ & Not specified & Not specified & Not specified \\
\hline [41] & 2012 & PROMITHEE & Not specified & Not specified & Not specified \\
\hline [42] & 2012 & $\begin{array}{l}\text { Fuzzy comprehensive } \\
\text { analysis method }\end{array}$ & Electronic products & Re-use, recycle & Disposition \\
\hline [43] & 2012 & TOPSIS & automobile & recycling & disposition \\
\hline [44] & 2013 & $\begin{array}{l}\text { ANP, grey relational } \\
\text { analysis }\end{array}$ & Not specified & Not specified & Not specified \\
\hline [45] & 2013 & ANP, TOPSIS & semiconductors & Not specified & Not specified \\
\hline [46] & 2013 & AHP, ANP & $\begin{array}{l}\text { Automobile } \\
\text { components }\end{array}$ & $\begin{array}{l}\text { Re-use, remanufacturing, } \\
\text { recycling }\end{array}$ & Collection \\
\hline [47] & 2013 & $\begin{array}{l}\text { Chance constrained free } \\
\text { disposal hull }\end{array}$ & Not specified & Not specified & Not specified \\
\hline [48] & 2014 & $\begin{array}{l}\text { Triangular fuzzy } \\
\text { numbers, neural } \\
\text { networks, PSO }\end{array}$ & Not specified & Not specified & Not specified \\
\hline [49] & 2014 & AHP, TOPSIS & Electronic products & Not specified & Not specified \\
\hline [50] & 2014 & AHP, PROMITHEE & Not specified & Not specified & $\begin{array}{l}\text { Collection, inspection, } \\
\text { disposition }\end{array}$ \\
\hline [51] & 2014 & AHP, TOPSIS & $\begin{array}{l}\text { Cell phones, } \\
\text { laptops, printers }\end{array}$ & Re-use, repair, recycle & collection \\
\hline [52] & 2014 & AHP, TOPSIS & Plastic bottles & recycle & Collection \\
\hline [49] & 2014 & AHP, TOPSIS & electronics & Not specified & Not specified \\
\hline [53] & 2014 & ISM, ELECTRE III & automobiles & Not specified & Disposition \\
\hline [54] & 2015 & $\mathrm{AHP}$ & automotive & Not specified & Not specified \\
\hline [16] & 2015 & Rash model analysis & e-waste & recycling & All activities in RL \\
\hline [55] & 2015 & DEA & Not specified & Not specified & Not specified \\
\hline [56] & 2015 & MCDA & Not specified & Not specified & Not specified \\
\hline [17] & 2015 & DEA, STATA & apparel & Repair, refurbish & All activities in $\mathrm{RL}$ \\
\hline [57] & 2015 & $\begin{array}{l}\text { AHP, grey relational } \\
\text { analysis }\end{array}$ & automotive & Not specified & Inspection, disposition \\
\hline [18] & 2016 & ANP, IFG-SIR & Composite pipes & recycling & Collection, disposition \\
\hline [58] & 2016 & ANP & Composite pipes & recycling & Collection, disposition \\
\hline [59] & 2016 & AHP, TOPSIS & electronics & $\begin{array}{l}\text { Re-use, recycle, repair, } \\
\text { remanufacturing }\end{array}$ & $\begin{array}{l}\text { Collection, inspection, } \\
\text { disposition }\end{array}$ \\
\hline [21] & 2016 & AHP, VIKOR & electronics & $\begin{array}{l}\text { Re-use, recycle, repair, } \\
\text { remanufacturing }\end{array}$ & collection \\
\hline [60] & 2016 & AHP, SWOT analysis & $\begin{array}{l}\text { Pipes, joints, } \\
\text { composite tanks }\end{array}$ & Not specified & Not specified \\
\hline [19] & 2017 & SWARA, MOORA & plastics & Not specified & All activities in RL \\
\hline [20] & 2018 & SWARA, COPRAS & $\begin{array}{l}\text { Exhaust systems, } \\
\text { bumpers }\end{array}$ & $\begin{array}{l}\text { Re-use, remanufacture, } \\
\text { recycle }\end{array}$ & All activities in RL \\
\hline [15] & 2018 & AHP, TOPSIS, PROMITHEE & Light bulbs & recycling & $\begin{array}{l}\text { Collection, inspection, } \\
\text { disposition }\end{array}$ \\
\hline
\end{tabular}

There is also a great difference between the first and second decades in the use of real case studies. The second decade saw an increase in the use of real case studies in the selection of 3PRLPs, and greater numbers of authors started applying their models and methods to real case studies. Most of the literature that does focus on real case studies also seems to focus more on discrete manufacturing, and specifically on electrical and electronic products. In this same area of discrete 
manufacturing, there is a need to explore products other than electronics. An example is the research carried out by Venkatesh et al. [17] in which they considered apparel. Tavana et al. [18] also looked into composite pipes. None of the research has focused on case studies from processing industries; yet these represent an interesting research topic, as they might present different disposition alternatives and examine how 3PLs can be used in such a setting - for example, in the production of steel and the re-use of scrap.

The most common methods used in evaluating and selecting 3PRLPs are mostly based on multicriteria decision-making methods, most of which are explained below.

a) Analytic hierarchy process (AHP): Saaty [61] proposed a pairwise comparison-based method in which a Multi-Criteria Decision Making (MCDM) problem is first formulated as a hierarchy of several levels. The first level represents the goal, the second level shows the main decision criteria, the next level shows the sub-criteria, and the last level indicates the alternatives. The elements of each level are compared in a pairwise fashion, forming a pairwise comparison matrix. Most articles among the selected papers used this method.

b) Analytic network process (ANP): ANP was proposed by Saaty [62] to address the interdependency and feedback problems between criteria - that is, any problems that cannot be handled by AHP.

c) Preference ranking organisation method for enrichment evaluations (PROMETHEE) is defined as a pairwise comparison-based outranking method that is used to solve MCDM problems. Different preference functions are used to convert pairwise comparisons to unicriterion preference degree. A multi-criteria preference degree is then calculated to compare the criteria with each other. Jihen, Mhamedi, and Chabchoub (2012) used this method in a fuzzy environment for the selection of 3PRLPs.

d) Technique for order preference by similarity to ideal solution (TOPSIS) was suggested by Hwang and Yoon [63]. According to convention, the best alternative is the one that has the shortest distance from the positive ideal solution and the farthest from the negative ideal solution.

e) Data envelopment analysis (DEA) was developed by Charnes, Cooper and Rhodes [64] to serve as a mechanism to evaluate the relative efficiencies of similar decision-making units (DMUs). DEA is a non-parametric mathematical tool.

f) Grey relational analysis (GRA): Pakkar [65] described grey relational analysis as being part of the grey system theory, proposed by Deng [66], that is suitable for solving a variety of MCDM problems with both crisp and fuzzy data. Pakkar [65] explained that GRA solved MCDM problems by aggregating multiple attribute values that are usually incommensurable into a single value for each alternative.

g) Neural networks: Kumar and Roy [67] stated that neural networks provide a new way for feature extraction (using hidden layers) and classification (e.g., the multilayer perceptron, which is essentially a linear classifier for classifying data specified by parameters and an output function).

Most authors combined popular methods into hybrids to obtain the best possible selection. Other robust multi-criteria decision-making methods have not been explored, and it would be interesting to see methods such as SAW (simple additive weighting) to evaluate the values of each alternative, or DEMATEL (Decision Making Trial and Evaluation Laboratory). There is also a need to expand and compare hybrid methodologies in 3PRLP selection. This seems to be an increasing trend among authors on the evaluation and selection of 3PRLPs.

\subsection{Closed loop supply chain effective operating modes}

Mode selection is when decisions have to be made about which reverse supply chain player has to be responsible for a certain operation in order to minimise costs and maximise profits for all players. Fleischmann [68] listed five main activities involved in reverse logistics: collection, transportation, inspection, disposition, and distribution and sales. In deciding on an operating mode, managers have to decide which RL operation can be performed by a 3PRLP, or a retailer, or even a manufacturer, and whether or not to keep the closed loop supply chain centralised. Nineteen per cent of the publications looked into the selection of operating modes. In a similar way to the evaluation and selection of 3PRLPs, the topic has more publications in the second decade than in the first decade. The literature on the selection of operating modes is summarised in Table 5. Most of the literature focuses predominantly on allocating the disposition and collection decisions between parties. There 
is some literature that combines both activities - for example, Karakayali, Emir-Farinas and Akcali [69] and Chiu, Lin and Hsu [70].

\section{Table 5: Literature on selecting operating modes}

\begin{tabular}{|c|c|c|c|c|}
\hline Authors and year & Main focus & Methodology & $\begin{array}{l}\text { Case study } \\
\text { product }\end{array}$ & Conclusion \\
\hline $\begin{array}{l}\text { Spicer and } \\
\text { Johnson } \\
(2004)[71]\end{array}$ & $\begin{array}{l}\text { Three options of } \\
\text { implementing EPR. OEM } \\
\text { take back, pooled take } \\
\text { back, and 3P take back }\end{array}$ & $\begin{array}{l}\text { Disassembly } \\
\text { model analyser } \\
\text { (DMA) }\end{array}$ & Renewit System & $\begin{array}{l}\text { 3P remanufacturing lowers } \\
\text { costs, but has information- } \\
\text { sharing problems }\end{array}$ \\
\hline $\begin{array}{l}\text { Savaskan, } \\
\text { Bhattacharya, and } \\
\text { Van Wassenhove } \\
(2004)[72]\end{array}$ & $\begin{array}{l}\text { Manufacturer with three } \\
\text { options of collection: } \\
\text { manufacturer collection, } \\
\text { retailer collection, and } \\
\text { 3PL collection }\end{array}$ & $\begin{array}{l}\text { Stackelberg } \\
\text { game model } \\
\text { with } \\
\text { manufacturer } \\
\text { as the leader }\end{array}$ & Not specified & $\begin{array}{l}\text { The agent closer to the } \\
\text { customer is the most effective } \\
\text { collector - that is, the retailer }\end{array}$ \\
\hline $\begin{array}{l}\text { Kumar and } \\
\text { Malegeant(2006) } \\
\text { [73] }\end{array}$ & $\begin{array}{l}\text { Collection strategies by } \\
\text { mail, local stores, and a } \\
3 \mathrm{P} \text { that is an NGO }\end{array}$ & $\begin{array}{l}\text { Game theory } \\
\text { Manufacturer- } \\
\text { led }\end{array}$ & NIKE shoes & $\begin{array}{l}\text { Sending shoes by mail is a win- } \\
\text { lose situation, collecting by } \\
\text { local stores is a lose-win } \\
\text { situation, and using NGO for } \\
\text { collection is a win-win situation }\end{array}$ \\
\hline $\begin{array}{l}\text { Karakayali et } \\
\text { al.(2007) [69] }\end{array}$ & $\begin{array}{l}\text { Situations that would } \\
\text { lead manufacturer to } \\
\text { outsource either } \\
\text { collection or recycling or } \\
\text { both }\end{array}$ & $\begin{array}{l}\text { Game theory } \\
\text { Manufacturer- } \\
\text { led }\end{array}$ & $\begin{array}{l}\text { Passenger vehicle } \\
\text { engines }\end{array}$ & $\begin{array}{l}\text { Practically , manufacturer } \\
\text { would prefer to outsource } \\
\text { collection. There are } \\
\text { conditions where they } \\
\text { outsource recycling }\end{array}$ \\
\hline $\begin{array}{l}\text { Huang, Yan, and } \\
\text { Qiu (2009)[74] }\end{array}$ & $\begin{array}{l}\text { Analysed product return } \\
\text { model, 3P collection } \\
\text { model, and } \\
\text { remanufacturing model }\end{array}$ & $\begin{array}{l}\text { H infinity } \\
\text { control }\end{array}$ & $\begin{array}{l}\text { Iron and steel } \\
\text { industry Bao Steel }\end{array}$ & Not specified \\
\hline $\begin{array}{l}\text { Sasikumar (2010) } \\
\text { [75] }\end{array}$ & $\begin{array}{l}\text { Compared three } \\
\text { operating modes: self- } \\
\text { support, joint venture, } \\
\text { and customer support }\end{array}$ & AHP & Not specified & Not specified \\
\hline Kaya(2010) [76] & $\begin{array}{l}\text { Analyse three different } \\
\text { models for centralised } \\
\text { and decentralised } \\
\text { settings, where } \\
\text { collection is managed by } \\
\text { collection agency in } \\
\text { decentralised setting, } \\
\text { and where return rate is } \\
\text { affected by incentive } \\
\text { offered by } \\
\text { manufacturer. }\end{array}$ & $\begin{array}{l}\text { Mathematical } \\
\text { model }\end{array}$ & Not specified & $\begin{array}{l}\text { It is much more important for } \\
\text { the collection agency to find } \\
\text { new ways to increase the } \\
\text { collection rates at a lower } \\
\text { cost, or to decrease the } \\
\text { remanufacturing costs, since } \\
\text { the manufacturer only does } \\
\text { remanufacturing if it is } \\
\text { profitable enough and they can } \\
\text { switch to the manufacturing of } \\
\text { original products without a } \\
\text { huge loss in the case of costly } \\
\text { remanufacturing }\end{array}$ \\
\hline $\begin{array}{l}\text { Chiu et al.(2011) } \\
\text { [70] }\end{array}$ & $\begin{array}{l}\text { Compared recycling by } \\
\text { manufacturers, retailers, } \\
\text { and 3PLs. }\end{array}$ & $\begin{array}{l}\text { Mathematical } \\
\text { model }\end{array}$ & Not specified & $\begin{array}{l}\text { Model in which 3PL leads } \\
\text { collection and then transfers } \\
\text { back to the manufacturer, for } \\
\text { remanufacturing is preferable. }\end{array}$ \\
\hline $\begin{array}{l}\text { Yan and Sun(2012) } \\
\text { [77] }\end{array}$ & $\begin{array}{l}\text { Centralised and } \\
\text { decentralised CLSC with } \\
\text { manufacturer and 3PRLP } \\
\text { and target rebate } \\
\text { contract }\end{array}$ & Game theory & $\begin{array}{l}\text { Steel and iron } \\
\text { scraps }\end{array}$ & $\begin{array}{l}\text { The target rebate contract may } \\
\text { coordinate the CLSC under } \\
\text { certain conditions }\end{array}$ \\
\hline $\begin{array}{l}\text { Zhang and Chen } \\
\text { (2012)[78] }\end{array}$ & $\begin{array}{l}\text { Dynamic game about } \\
\text { government, } \\
\text { manufacturers, 3PLs, } \\
\text { and consumers }\end{array}$ & Game theory & Electronics & Not specified \\
\hline Senthil (2012)[79] & $\begin{array}{l}\text { Selection of RL operating } \\
\text { channels between } \\
\text { manufacturer operation, } \\
\text { 3P operation, and joint } \\
\text { operation }\end{array}$ & $\begin{array}{l}\text { AHP and } \\
\text { TOPSIS }\end{array}$ & $\begin{array}{l}\text { Printing industry, } \\
\text { magazines, and } \\
\text { papers }\end{array}$ & $\begin{array}{l}\text { 3P operation better than oint } \\
\text { operation, which is better than } \\
\text { manufacturer operation }\end{array}$ \\
\hline $\begin{array}{l}\text { Hong and } \\
\text { Yeh(2012) [80] }\end{array}$ & $\begin{array}{l}\text { Compared retailer } \\
\text { collection and } 3 \mathrm{PL} \\
\text { collection where } \\
\text { manufacturer and } 3 \mathrm{PL} \\
\text { cooperate to handle } \\
\text { used products }\end{array}$ & $\begin{array}{l}\text { Mathematical } \\
\text { model }\end{array}$ & Electronics & $\begin{array}{l}\text { While return rate, } \\
\text { manufacturer profit, and other } \\
\text { channel member profits are not } \\
\text { superior to non-retailer } \\
\text { collection, retailer collection } \\
\text { outperforms when the } 3 \mathrm{PL} \text { is an } \\
\text { NGO for recycling and disposal }\end{array}$ \\
\hline
\end{tabular}




\begin{tabular}{|c|c|c|c|c|}
\hline Authors and year & Main focus & Methodology & $\begin{array}{l}\text { Case study } \\
\text { product }\end{array}$ & Conclusion \\
\hline Wei (2013)[81] & $\begin{array}{l}\text { Inventory implications of } \\
\text { three different } \\
\text { production collection } \\
\text { modes - that is, } \\
\text { manufacturer, retailer, } \\
\text { and } 3 P \text { - on decisions of } \\
\text { manufacturer, retailer, } \\
\text { and } 3 P \text {, and on profits }\end{array}$ & Game theory & $\begin{array}{l}\text { Electrical } \\
\text { products }\end{array}$ & $\begin{array}{l}\text { Maximum expected profit } \\
\text { optimal with manufacturer } \\
\text { collection } \\
\text { Optimal collection rate high for } \\
\text { manufacturer collection }\end{array}$ \\
\hline $\begin{array}{l}\text { Choi, Li, and Xu } \\
(2013) \text { [82] }\end{array}$ & $\begin{array}{l}\text { Different channel } \\
\text { leadership i. } \\
\text { manufacturer led, ii. } \\
\text { retailer led, iii. collector } \\
\text { led }\end{array}$ & Game theory & KODAK cameras & $\begin{array}{l}\text { The retailer-led model is the } \\
\text { most effective }\end{array}$ \\
\hline $\begin{array}{l}\text { Chuang, Wang, } \\
\text { and Zhao } \\
(2014)[83]\end{array}$ & $\begin{array}{l}\text { Three alternatives of } \\
\text { reverse channel } \\
\text { structures of collection: } \\
\text { i. manufacturer } \\
\text { collection, ii. retailer } \\
\text { collection, iii. 3P } \\
\text { collection }\end{array}$ & $\begin{array}{l}\text { News vendor } \\
\text { model }\end{array}$ & $\begin{array}{l}\text { High-tech } \\
\text { products }\end{array}$ & $\begin{array}{l}\text { Under symmetric cost } \\
\text { structures, retailer collection is } \\
\text { optimal; and under } \\
\text { asymmetrical cost structures, } \\
\text { manufacturer collection is } \\
\text { optimal }\end{array}$ \\
\hline $\begin{array}{l}\text { Hong, } \mathrm{Xu}, \mathrm{Du} \text {, and } \\
\text { Wang (2015)[84] }\end{array}$ & $\begin{array}{l}\text { Choosing between three } \\
\text { types of collection - i.e., } \\
\text { manufacturer collection, } \\
\text { retailer collection, and } \\
\text { 3PL collection }\end{array}$ & $\begin{array}{l}\text { Game theory } \\
\text { Manufacturer } \\
\text { led }\end{array}$ & Not specified & $\begin{array}{l}\text { It is optimal for manufacturer } \\
\text { to authorise retailer to collect } \\
\text { products }\end{array}$ \\
\hline $\begin{array}{l}\text { Jindal and } \\
\text { Sangwan(2015) } \\
\text { [85] }\end{array}$ & $\begin{array}{l}\text { Three collection } \\
\text { methods - manufacturer, } \\
\text { retailer, or } 3 \mathrm{PL} \text {. }\end{array}$ & AHP, TOPSIS & Automobiles & $\begin{array}{l}\text { Retailer collection is best for } \\
\text { high values of cost parameter, } \\
\text { and } 3 \mathrm{P} \text { collection is always the } \\
\text { worst }\end{array}$ \\
\hline $\begin{array}{l}\text { Abdulrahman, } \\
\text { Subramanian, Liu, } \\
\text { and Shu (2015)[86] }\end{array}$ & $\begin{array}{l}\text { investigated key } \\
\text { determinants for } \\
\text { strategic decision- } \\
\text { making to } \\
\text { remanufacture in-house, } \\
\text { outsource } \\
\text { remanufacturing, and/or } \\
\text { not to engage in } \\
\text { remanufacturing }\end{array}$ & $\mathrm{AHP}$ & $\begin{array}{l}\text { Chinese auto } \\
\text { parts }\end{array}$ & Not specified \\
\hline $\begin{array}{l}\text { Shi , Nie and Qu } \\
(2015)[87]\end{array}$ & $\begin{array}{l}\text { Three collection modes - } \\
\text { manufacturer collection, } \\
\text { retailer collection, and } \\
\text { 3P collection }\end{array}$ & $\begin{array}{l}\text { Mathematical } \\
\text { model }\end{array}$ & Not specified & $\begin{array}{l}\text { Collection by the manufacturer } \\
\text { is the best choice, retailer } \\
\text { collection will be best for high } \\
\text { cost parameter. From the point } \\
\text { of view of the retailer, } 3 P \\
\text { collection is the worst choice }\end{array}$ \\
\hline $\begin{array}{l}\text { Hong, Zhang, } \\
\text { Zhong, and Liu } \\
\text { (2016) [88] }\end{array}$ & $\begin{array}{l}\text { Three options for } \\
\text { collecting used products: } \\
\text { i. manufacturer and } \\
\text { retailer collection, } \\
\text { ii.retailer and 3P } \\
\text { collection, iii. } \\
\text { manufacturer and 3P } \\
\text { collection }\end{array}$ & Game theory & $\begin{array}{l}\text { Single use } \\
\text { cameras, mobile } \\
\text { phones }\end{array}$ & $\begin{array}{l}\text { Manufacturer and retailer } \\
\text { hybrid collection works best }\end{array}$ \\
\hline $\begin{array}{l}\text { Yi, Huang, Guo, } \\
\text { and Shi (2016) [89] }\end{array}$ & $\begin{array}{l}\text { Optimum collection } \\
\text { strategies where the } \\
\text { manufacturer makes new } \\
\text { products and the retailer } \\
\text { remanufactures. The } \\
\text { retailer and the 3P } \\
\text { simultaneously collect } \\
\text { used products }\end{array}$ & Game theory & Excavators & $\begin{array}{l}\text { Allocated collecting regions to } \\
\text { retailer and } 3 \mathrm{P} \text { for collection }\end{array}$ \\
\hline $\begin{array}{l}\text { Aydin, Kwong, and } \\
\mathrm{Ji}(2016) \text { [90] }\end{array}$ & $\begin{array}{l}\text { Model the coordination } \\
\text { of an OEM and supply } \\
\text { chain parties }\end{array}$ & Game theory & Tablet PCs & Not specified \\
\hline $\begin{array}{l}\text { Zheng and Wu } \\
\text { (2016) [91] }\end{array}$ & $\begin{array}{l}\text { System made up of } \\
\text { manufacturer, retailer, } \\
\text { and } 3 \mathrm{P} \text { recycler and } \\
\text { market segmentation. } \\
\text { Set up a model with } 3 \mathrm{P} \\
\text { collection }\end{array}$ & Game theory & Not specified & Not specified \\
\hline $\begin{array}{l}\text { Miao, Wang, and } \\
\text { Chen (2017) [92] }\end{array}$ & $\begin{array}{l}\text { Contrasts recycling at } \\
\text { home and abroad and } \\
\text { recycling model by } 3 \mathrm{P} \\
\text { enterprises, and } \\
\text { compares total revenues } \\
\text { of supply chains }\end{array}$ & $\begin{array}{l}\text { Systems } \\
\text { dynamics }\end{array}$ & $\begin{array}{l}\text { Household } \\
\text { appliances } \\
\text { Midea Corp }\end{array}$ & $\begin{array}{l}\text { 3P recycling is more effective } \\
\text { than manufacturer recycling, } \\
\text { both at home and abroad }\end{array}$ \\
\hline
\end{tabular}




\begin{tabular}{|c|c|c|c|c|}
\hline Authors and year & Main focus & Methodology & $\begin{array}{l}\text { Case study } \\
\text { product }\end{array}$ & Conclusion \\
\hline $\begin{array}{l}\text { Liu, Wang, Xu, } \\
\text { Hong, and } \\
\text { Govindan (2017) } \\
\text { [93] }\end{array}$ & $\begin{array}{l}\text { The OEM has to choose } \\
\text { between three } \\
\text { alternatives: i. OEM and } \\
\text { retailer collection, ii. } \\
\text { Retailer and } 3 P \\
\text { collection, iii. OEM and } \\
3 P \text { collection }\end{array}$ & Game theory & Not specified & $\begin{array}{l}\text { OEM and retailer dual } \\
\text { collection model is the best } \\
\text { model }\end{array}$ \\
\hline Giri (2017) [94] & $\begin{array}{l}\text { Pricing and retailer } \\
\text { collection decisions for } \\
\text { five scenarios: } \\
\text { centralised, } \\
\text { decentralised, } \\
\text { manufacturer-led, } \\
\text { retailer-led, and 3P-led } \\
\text { collection for a CLSC } \\
\text { with two dual channels - } \\
\text { forward and reverse dual } \\
\text { channel. }\end{array}$ & $\begin{array}{l}\text { Mathematical } \\
\text { model }\end{array}$ & Not specified & $\begin{array}{l}\text { Retailer-led decentralised } \\
\text { scenario provides more profit } \\
\text { than other decentralised } \\
\text { scenarios }\end{array}$ \\
\hline Wang (2017) [95] & $\begin{array}{l}\text { Remanufacturer's } \\
\text { recycle strategy, three } \\
\text { models, and } \\
\text { remanufacturer, } \\
\text { authorised retailer, or } \\
\text { authorized 3P. Decision } \\
\text { model with and without } \\
\text { loan strategy. }\end{array}$ & $\begin{array}{l}\text { Mathematical } \\
\text { model }\end{array}$ & Not specified & $\begin{array}{l}\text { When loan strategy is adopted, } \\
\text { profit for each SC member } \\
\text { decreases when rate increases, } \\
\text { no matter which model is used. } \\
\text { Compared with non-loan } \\
\text { strategy, profit of } \\
\text { remanufacturer and 3P } \\
\text { increase when loan strategy is } \\
\text { adopted and it's uncertain for } \\
\text { retailer }\end{array}$ \\
\hline
\end{tabular}

It would be interesting to find literature on a scenario where there is a comparison of operating modes for all the reverse logistics activities. Some activities, such as transportation, inspection, and reselling have also not been looked into. Most of the literature on the selection of operating modes focuses on specific products and case studies. However, most of the publications still focus on electronic products, and this also leaves a gap for other products. The conclusion that retailer collection is the best method has been reached by the majority of authors, but since most of the studies are on electronic products, there is a need to explore whether the same conclusion applies to other product types.

\subsection{Influential issues}

Influential issues highlight those that will affect the decision about outsourcing reverse logistics activities. Krumwiede (2002) provided a decision-making model to guide the process of examining the feasibility of implementing RL in 3PLs, by examining issues and processes addressed by organisations to engage in the RL business. Influential issues have evolved from the exploration of the feasibility of outsourcing reverse logistics by Krumwiede and Sheu [96] and Ordoobadi [97], to exploring roles played by 3PLs in reverse logistics by Shaharudin, Zailani and Ismail [98] and Shaharudin, Zailani and Muhazir [99]. Li, Kannan, Garg, Gupta, Gandhi, and Jha [100] demonstrated that influential issues mostly focus on defining a benchmark for best practices of recovery operations by 3PRLPs. This evolution of influential issues is summarised in Table 6. Some authors, however, focused on analysing outsourcing decisions in specific regions. Verstrepen, Cruijssen, Brito and Dullaert [101] explored reverse logistics in Flanders for shippers and logistics service providers, while Klapalová [102] carried out an exploratory study on outsourcing reverse logistics in the Czech Republic, among four industry sectors. Netro, Álvarez, Carrillo, and Flores (2016) also investigated the handling of municipal solid and special handling waste by comparing domestic waste and construction offshore platform waste in Mexico.

\subsection{Network design}

Network design involves the location and allocation of facilities in a reverse logistics network with 3PRLPs. Network design can be for the 3PRLP or the manufacturer. Seventeen per cent of the publications focused on network design issues. The majority of the publications focused on designing networks for the 3PRLPs rather than for the original manufacturers.

Lee, Bian and Dong [118] and [119] designed reverse logistics networks for 3PRLPs involved in both forward and reverse logistics to locate warehouses and collecting centres. These facilities were to assist the 3PRLPs to distribute products to their various customers. The same issue was also looked into by Ko and Evans [120] and Hyangsook, Zhang and Boile [121]. 
Table 6: Summary of influential issues

\begin{tabular}{|c|c|c|c|}
\hline $\begin{array}{l}\text { Author and } \\
\text { year }\end{array}$ & Main focus & Author and year & Main focus \\
\hline $\begin{array}{l}\text { Krumwiede } \\
\text { and Sheu } \\
(2002)[96]\end{array}$ & $\begin{array}{l}\text { Decision-making model to guide } \\
\text { the process of examining the } \\
\text { feasibility of employing 3PRLPs. }\end{array}$ & $\begin{array}{l}\text { Ordoobadi } \\
(2007)[97]\end{array}$ & $\begin{array}{l}\text { Examined the strategic and } \\
\text { economic feasibility of an } \\
\text { outsourcing decision. }\end{array}$ \\
\hline $\begin{array}{l}\text { Serrato et } \\
\text { al.(2007) [104] }\end{array}$ & $\begin{array}{l}\text { Explored the hypothesis that } \\
\text { outsourcing RL functions is } \\
\text { more suitable when returns are } \\
\text { more variable. }\end{array}$ & $\begin{array}{l}\text { Verstrepen et } \\
\text { al. (2007) [101] }\end{array}$ & $\begin{array}{l}\text { Explored RL in Flanders for shippers } \\
\text { and logistics service providers and } \\
\text { pointed out low performance areas } \\
\text { for improvement. }\end{array}$ \\
\hline $\begin{array}{l}\text { Guo and Li } \\
(2008)[105]\end{array}$ & $\begin{array}{l}\text { Established a theory to solve a } \\
\text { decision-making problem of } \\
\text { outsourcing in an automobile } \\
\text { company }\end{array}$ & $\begin{array}{l}\text { Logozar (2008) } \\
{[106]}\end{array}$ & $\begin{array}{l}\text { Pointed out motivations for } \\
\text { outsourcing, evidence for } \\
\text { outsourcing, and analysed } \\
\text { outsourcing reverse logistics. }\end{array}$ \\
\hline $\begin{array}{l}\text { Zhang and Sun } \\
(2008) \text { [107] }\end{array}$ & $\begin{array}{l}\text { Considered key factors for the } \\
\text { selection of logistics service } \\
\text { providers according to different } \\
\text { partnerships. }\end{array}$ & $\begin{array}{l}\text { Martin, Guide, } \\
\text { and Craighead } \\
(2010)[108]\end{array}$ & $\begin{array}{l}\text { Formulated hypothesis based on in- } \\
\text { house versus contracted } \\
\text { remanufacturing operations. }\end{array}$ \\
\hline $\begin{array}{l}\text { Nikolaidis } \\
\text { (2009)[109] }\end{array}$ & $\begin{array}{l}\text { Proposed a mathematical model } \\
\text { to help remanufacturers to } \\
\text { make optimal decisions on the } \\
\text { quantities to be purchased and } \\
\text { quantities to be } \\
\text { remanufactured. }\end{array}$ & $\begin{array}{l}\text { Meng (2010) } \\
{[110]}\end{array}$ & $\begin{array}{l}\text { Judged the risks of outsourcing } \\
\text { reverse logistics. }\end{array}$ \\
\hline $\begin{array}{l}\text { Lambert, } \\
\text { Riopel, and } \\
\text { Abdul-kader } \\
\text { (2011)[111] }\end{array}$ & $\begin{array}{l}\text { Proposed a RL conceptual } \\
\text { framework that considers a } \\
\text { wide variety of situations in a } \\
\text { working environment. }\end{array}$ & $\begin{array}{l}\text { Murali, } \\
\text { Pugazhendhi, } \\
\text { and Ganesh } \\
\text { (2011) [112] }\end{array}$ & $\begin{array}{l}\text { Focused on issues relating to } \\
\text { employing 3PRLPs and a brief } \\
\text { evaluation of 3PRLPs. }\end{array}$ \\
\hline $\begin{array}{l}\text { Sharif, Irani, } \\
\text { and Love } \\
(2012)[113]\end{array}$ & $\begin{array}{l}\text { Conceptual framework of } \\
\text { factors affecting reverse } \\
\text { logistics based on information } \\
\text { systems and associated resource } \\
\text { commitment factors. }\end{array}$ & $\begin{array}{l}\text { Klapalová (2012) } \\
\text { [102] }\end{array}$ & $\begin{array}{l}\text { Exploratory study of outsourcing } \\
\text { reverse logistics in Czech Republic } \\
\text { among four industry sectors. }\end{array}$ \\
\hline $\begin{array}{l}\text { Janusz and Kot } \\
\text { (2010) }[114]\end{array}$ & $\begin{array}{l}\text { Concept in outsourcing of RL, } \\
\text { advantages of outsourcing, and } \\
\text { types of relationships between } \\
\text { partners. }\end{array}$ & $\begin{array}{l}\text { Krikke, Hofenk, } \\
\text { and Wang (2013) } \\
{[115]}\end{array}$ & $\begin{array}{l}\text { Comprehensive descriptive statistics } \\
\text { on the analysis of current practices. } \\
\text { Showed inefficiencies and compared } \\
\text { regions and industries. }\end{array}$ \\
\hline $\begin{array}{l}\text { Shaharudin et } \\
\text { al. (2014) [98] }\end{array}$ & $\begin{array}{l}\text { Theoretical framework to study } \\
\text { orchestrator role of 3PLs in } \\
\text { reverse logistics. }\end{array}$ & $\begin{array}{l}\text { Badenhorst \& } \\
\text { Van Zyl (2015) } \\
{[116]}\end{array}$ & $\begin{array}{l}\text { Explored possibilities of outsourcing } \\
\mathrm{RL} \text { and presented findings in a } \\
\text { conceptual framework. }\end{array}$ \\
\hline $\begin{array}{l}\text { Shaharudin et } \\
\text { al. (2015) [99] }\end{array}$ & $\begin{array}{l}\text { Explained three green strategic } \\
\text { orientations of } 3 \text { PLs in reverse } \\
\text { logistics: innovation-based, } \\
\text { efficiency-based, and } \\
\text { reputation-based. }\end{array}$ & $\begin{array}{l}\text { Cruz et al.(2016) } \\
{[103]}\end{array}$ & $\begin{array}{l}\text { Investigated the handling of } \\
\text { municipal solid and special handling } \\
\text { waste. Compared domestic waste } \\
\text { and construction offshore platform } \\
\text { wastes, and suggested a 3PL to } \\
\text { recover special handling waste. }\end{array}$ \\
\hline $\begin{array}{l}\text { Agrawal, } \\
\text { Singh, and } \\
\text { Murtaza } \\
\text { (2016) [117] }\end{array}$ & $\begin{array}{l}\text { Framework for outsourcing } \\
\text { reverse logistics by varying the } \\
\text { extent of outsourcing RL under } \\
\text { four scenarios. }\end{array}$ & $\begin{array}{l}\text { Li et al.(2018) } \\
{[100]}\end{array}$ & $\begin{array}{l}\text { Tried to establish a benchmark for } \\
\text { recovery processes by 3PRLPs by } \\
\text { evaluating design criteria, } \\
\text { implementation criteria, process } \\
\text { control characteristics, and business } \\
\text { orientation policies. }\end{array}$ \\
\hline
\end{tabular}

The year 2008 saw the design of after-sales networks and mostly-repair networks. Authors such as Kusumastuti, Piplani and Hian Lim [122] and Min and Ko [123] developed closed loop repair networks with the aim of locating and allocating repair facilities for 3PLs. Kusumastuti, Piplani and Lim [122] further focused on part manufacturers and third party vendors who have offshored to other countries in computer manufacturing. Hao, Xu, Liu and Liu [124] also focused on the design of an after-sales network to minimise the network design cost for a 3PRLP.

Instead of focusing on the location and allocation of facilities, Lin, Lee and Lee [125] developed a reverse logistics decision model for a logistics service provider to determine optimal quantities of customer orders and processing quantities of returned products at each facility. Das and Chowdhury [126] also developed a planning model for the collection of returned products, recovery of modules, and product mix of different quality levels. They focused on a closed loop system with different quality products and a modular product design. A $3 \mathrm{PL}$ that had already been provided with collection 
centres and reprocessing facilities was considered by Suyabatmaz, Altekin and Sahin [127]. Their problem was to find the number and location of test centres associated with the quantity of returns for the 3PL.

Some of the literature on network design was specific to a particular area. Mahmoudzadeh, Mansour and Karimi [128] modelled the managing and processing of end-of-life vehicles in Iran as a 3PRLP network. They determined the optimal locations and allocations of scrapyards in the country. Similarly, Alshamsi and Diabat [129] focused on the Gulf Cooperation Region to develop the optimum location and capacity of inspection centres and remanufacturing facilities. They considered 68 cities to determine whether or not to outsource the reverse logistics activities.

Designing reverse logistics networks for 3PLs was extended by Kannan, Garg, Jha and Diabat [130] when they integrated the concept of line balancing in planning a recovery network for a 3PRLP. Li and Huang [131] also considered the presence of proactive attacks and their impact on the design of a reliable reverse logistics network for a 3PRLP.

While the majority of the authors designed networks for 3PRLPs, two of the authors designed networks for the original manufacturer. Yu and Solvang [132] developed a general reverse logistics network for a manufacturer with a 3PRLP, not only to minimise costs, but also to minimise emissions. Darbari, Kannan, Agarwal and Jha [133] designed a closed loop system for an Indian laptop manufacturer with manufacturers, suppliers, 3PLs (both forward and reverse), retailers, and an NGO, based on the triple bottom line approach. The main objective was to minimise environmental impact at the same time as maximising net profit and social impact.

The literature on network design mostly applies operations research methods of integer and linear programming. It would be interesting to see the literature employing different methodologies, such as network flow algorithms and simulations. The literature also needs to expand the concept of network design by including other aspects that have an impact on the topic - for example, the research done by Kannan et al. [130] that incorporated line balancing into network design. Concepts like cross-docking, warehousing, etc. can also be incorporated into network design for 3PRLPs. There is also a need for more literature that branches from the usual location and allocation of facilities and focuses on other aspects, such as processing and delivery quantities.

\subsection{Competition}

There is usually competition when a $3 \mathrm{PL}$ is not working with the original equipment manufacturer in the reverse logistics process. Some 3PLs collect and reprocess products for their own business, without any contact or relationship with the original equipment manufacturer. Not many authors have explored this aspect of reverse logistics.

3PLs not only compete with original equipment manufacturers in collecting used products, but also in selling them. Market cannibalisation has been one of the concerns of reverse logistics. For this reason, most manufacturers seek control of their used products. Competition in reverse logistics has mostly been investigated using game theories and mathematical models. Ferguson and Toktay [134] developed game models to assist a manufacturer's recovery strategy in the face of a competitive threat in the remanufacturing market. Competition came not only from the manufacturer selling both new and old products, but also from an independent remanufacturer selling old products in the same market. Bulmus, Zhu and Teunter [135] not only focused on market cannibalisation; they also combined market cannibalisation and the competition for remanufacturing cores between a manufacturer and an independent remanufacturer. The manufacturer and independent remanufacturer competed, through prices, both in the market and in collecting used products. This was the only publication that looked at both types of competition.

Most publications focused on competition in collecting used products (cores). Webster and Mitra [136] considered the impact of waste electrical and electronic equipment (WEEE ) take-back laws on the competition between the manufacturer and independent remanufacturers for cores. They considered two situations: one in which the manufacturer has no control over product returns, and the other when there is complete control over product returns. Mitra and Webster [137] investigated the impact of government subsidies when the manufacturer and the remanufacturer compete for markets. The manufacturer only sold new products, and the remanufacturer, encouraged by the subsidies, collected and sold used products. The manufacturer was given a chance to determine the quality of both used and new products in the face of competition for cores, in research by Orsdemir, 
Kemahhoglu-Ziya and Parlakturk [138]. In this setting, the manufacturer and remanufacturer competed in determining their production quantities.

The literature on competition is still very sparse to begin with. A gap was closed by Bulmus et al. [135] in their research, when they combined competition for cores and competition for market. There is no other publication to compare with this research, and there is still a need to explore the combination of both types of competition. Most literature on competition employed game theory without validating their models with empirical research. It is necessary to find empirical research to validate the conclusions of the publications.

The impact of the product life cycle on competition is also worth investigating. Research should also consider the impact of this competition on the three dimensions of sustainability.

\subsection{Performance measurement}

Neely, Gregory and Platts [139] defined performance measurement as "the process of quantification and action correlates with performance". Performance should be defined as the efficiency and effectiveness of the action. In this context, of the 134 articles, only three focused on the performance measurement of reverse logistics systems with 3PRLPs. These three publications appeared only in the second decade, which shows that the topic has never been explored before, and still has potential for more research.

Bai and Sarkis [140] evaluated the flexibility of a 3PRLP. They focused on operational (production and volume) flexibility and strategic (network and organisational design) flexibility. Hosoda, Altekin and Sahin [141] measured the production and net stock variance for a manufacturer. They investigated the impact of the manufacturer obtaining advance notice on product returns from the remanufacturer. They established that sharing information is beneficial. The 'bullwhip effect' in a closed loop supply chain was measured by He, Yuan and Zhang [142], who investigated the influence of a recycler's behaviour based on the government's policy index. The findings revealed that a larger environmental policy index leads to a greater recycle proportion, and that this weakens the retailer's order rate in the forward supply chain. However, it also strengthened the reverse supply chain bullwhip effect.

Because the literature on performance measurement seems so limited, it is necessary to identify gaps that have yet to be explored. Agrawal and Choudhary [143] identified the main dimensions in reverse logistics performance measurement, and explained the three main perspectives in RL performance measure. Table 7 identifies the measures in these three perspectives, and how the current literature lacks research in RL performance measure.

The shaded areas represent the branches of performance measurement that have been looked into by the three publications. The literature on its own is too small to be conclusive. Performance measurement still needs to be explored in all its aspects.

Table 7: Research gaps in performance measurement

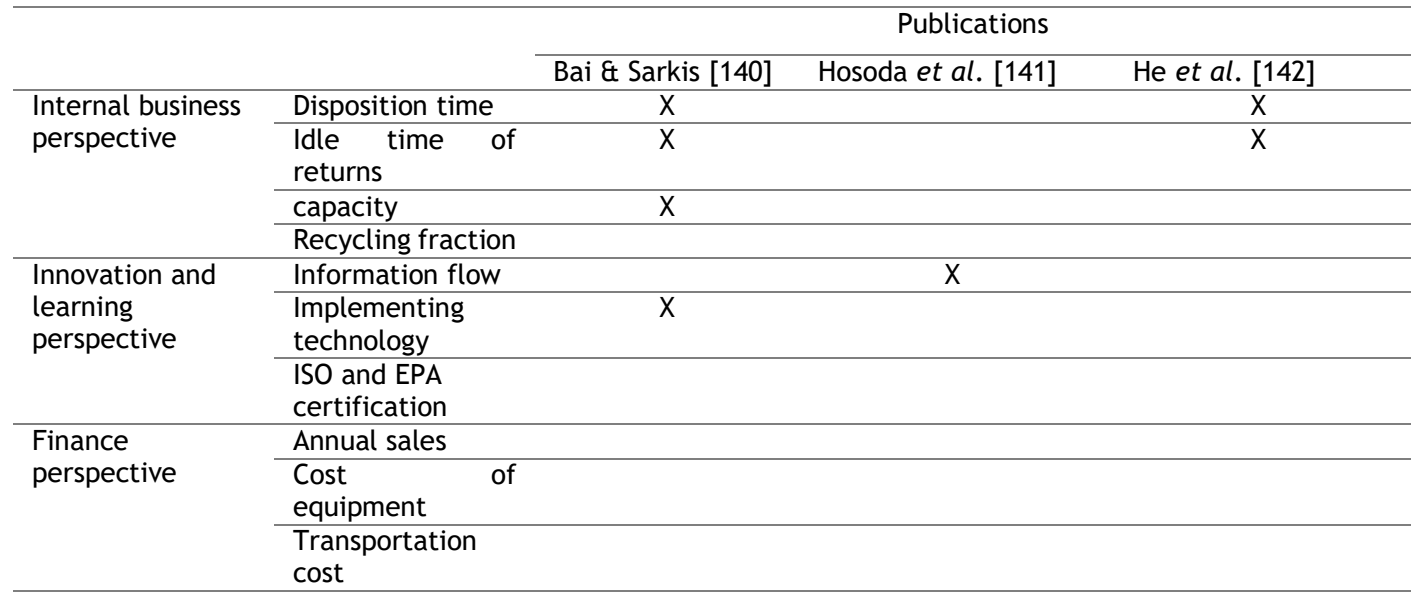


The innovation and learning perspective focuses on issues such as information flow, which can be an indicator in performance measures such as the bullwhip effect. As Lee, Padmanabhan, and Whang (1997) mentioned, this lack of information sharing is one of the causes of the bullwhip effect. Research on the innovation and learning perspective can be expanded to consider the impact of 3PRLPs on the activities and performance of the forward chain, such as the bullwhip effect, inventory management, production planning, etc. Adenso-Diaz, Moreno, Gutierrez, and Lozano (2012) mentioned factors such as the recycler's collection rate and capacity as factors worth considering when measuring supply chain performance in the presence of reverse logistics.

The research also did not consider performance measurement from the finance perspective. Although these issues are usually considered in the selection of 3PRLPs, it becomes necessary to compare supply chain profits in the presence and absence of 3PRLPs. The topic can also be expanded by looking into the impact of reverse logistics activities on the profits and costs of the company offering the services - i.e., the 3PRLPs themselves. Although the internal business perspective is the area most looked into, there is a need for more research on all aspects of performance measurement.

\subsection{Production planning and inventory control issues}

Unlike the concept of performance measurement, which was introduced in the second decade, production planning and inventory control issues were investigated in both decades. Most authors, however, expressed little or no interest in the topic. Only three publications could be found.

Galbreth and Blackburn [146] examined the case of a remanufacturer who acquired unsorted products from a 3P collecting agent, thus focusing on the acquisition and sorting processes. They had to decide how many products to acquire, and how selective to be, during sorting under conditions of both certain and uncertain demand. With the aim of maximising joint profits for the supplier, manufacturer, 3P recycler, and retailer, Chung, Wee and Yang [147] analysed an inventory model with traditional forward material flow and a reverse flow. In the reverse flow, used products were returned, remanufactured, and shipped to the retailer for resale.

In a model where a remanufacturer supplies two closely related components to a manufacturer with used products being recovered by a 3P provider, Jung, Dawande, Geismar, Guide Jr, and Sriskandarajah [148] developed optimal plans for different production strategies. They specified the quantity of components that had to be remanufactured, those that had to be purchased from suppliers, and those for disposal. They also explored the effects of production capacity on these optimal production plans.

Production planning and inventory control issues always have an impact, not only from the innovative and learning perspective, but also from a financial perspective. There is a real need to develop integrated models for production planning and inventory control for 3PRLPs. These may affect not only the 3PRLP, but also the original equipment manufacturer. There is a need to explore different inventory control and production planning methods to determine their suitability when combined with reverse logistics. This can also be expanded to consider different types of products in such issues.

\subsection{Combination of issues}

Some authors combined topics from the categories listed above. This combination of topics mostly emerged in the second decade. This is a good expansion of the literature, since there is always more than one issue to consider in incorporating a supply chain, and focusing on only one chain oversimplifies the overall problem. Five publications exist for the combined topics.

The most common combination is that of network design and 3PRLP evaluation and selection. Kafa, Hani and El Mhamedi [149] proposed an integrated sustainable network for the selection of 3PRLPs and closed loop network configuration, specifically in outsourcing reverse logistics; while Wu and Barnes [150] presented a model for partner selection for reverse logistics centres in green supply chains. Govindan, Agarwal, Darbari and Jha [151] also proposed an integrated SC network for the evaluation and selection of forward distribution partners (FDP) and third party reverse logistic providers.

A combination of network design and production planning and inventory issues was offered by Li, Guo and Zhang [152], who studied the location and inventory decisions jointly in a closed loop supply 
chain with a 3PL. Huang, Song, Lee and Ching [153] followed a different approach, when they focused on the selection of effective operating modes and competition. The authors compared a closed loop system in which a retailer and a $3 \mathrm{P}$ simultaneously and competitively collect products with systems in which either the retailer or the $3 \mathrm{P}$ collects products. This was done to establish the best recycling channel.

These five publications present a gap that can be explored, as far as combining issues related to 3PRLPs is concerned, and more combinations can be explored. Even more than two issues can be looked into in one publication as an extension of the research.

\subsection{Other issues}

Issues that involve 3PLs in reverse logistics, but that do not fall under the seven categories explained in the previous sections, have been classified as 'other issues'. These publications and their focus are summarised in Table 8.

The overall placement of the literature, according to the reverse logistic activities of collection, transportation, inspection, disposition, and distribution and sales is summarised in Figure 5. Some of the literature has been classified as general because it is not specified on which reverse logistics activity it focuses.

The majority of the literature does not specify the focus of 3PRLPs; they just describe general activities. Of those that are specific, most focus on collection. This means that there is a need for literature that focuses on 3PLs in other aspects of reverse logistics such as transportation, inspection, and distribution and sales. There is also a need for literature on situations in which a 3PL performs more than one activity, such as in the case of Agrawal et al.[154].

Table 8: Summary of the literature on other issues

\begin{tabular}{|c|c|c|c|c|c|}
\hline Author & Focus & Objectives & Author & Focus & Objectives \\
\hline $\begin{array}{l}\text { Ding et } \\
\text { al. } \\
\text { [155] }\end{array}$ & $\begin{array}{l}\text { Principles of } \\
\text { construction and } \\
\text { optimisation of } \\
\text { eco-industrial } \\
\text { parks }\end{array}$ & $\begin{array}{l}\text { Introduce 3PRLPs to } \\
\text { improve efficiency in } \\
\text { recycling. Also } \\
\text { improve profit } \\
\text { models for 3PRLPs. }\end{array}$ & $\begin{array}{l}\text { Krikke \& } \\
\text { Van der } \\
\text { Laan [156] }\end{array}$ & $\begin{array}{l}\text { ConRepair, a } \\
\text { 3P service } \\
\text { provider in } \\
\text { mainframes }\end{array}$ & $\begin{array}{l}\text { Discussed how } \\
\text { service repair firms } \\
\text { apply reverse } \\
\text { logistics in } \\
\text { supplying spare } \\
\text { parts for servicing } \\
\text { ageing mainframe } \\
\text { plant control } \\
\text { systems. }\end{array}$ \\
\hline $\begin{array}{l}\text { Bogh et } \\
\text { al. } \\
{[157]}\end{array}$ & $\begin{array}{l}\text { Considered } \\
\text { outsourcing of } \\
\text { planning and } \\
\text { transportation of } \\
\text { paper and glass } \\
\text { collected from } \\
\text { recycling cubes }\end{array}$ & $\begin{array}{l}\text { Showed how } \\
\text { outsourcing could } \\
\text { create a conflict of } \\
\text { interest. Suggested } \\
\text { payment structure } \\
\text { for overall financial } \\
\text { sustainability for } \\
\text { both the company } \\
\text { and the 3PL. }\end{array}$ & $\begin{array}{l}\text { Selviaridis } \\
\text { et al. } \\
\text { [158] }\end{array}$ & $\begin{array}{l}\text { Service } \\
\text { supply chain } \\
\text { of returnable } \\
\text { transport } \\
\text { packaging }\end{array}$ & $\begin{array}{l}\text { Explored how } \\
\text { reverse resource } \\
\text { exchanges and } \\
\text { resource } \\
\text { dependencies are } \\
\text { managed in a } \\
\text { service supply } \\
\text { chain. }\end{array}$ \\
\hline $\begin{array}{l}\text { Batarfi } \\
\text { et al. } \\
{[159]}\end{array}$ & $\begin{array}{l}\text { Reverse logistics } \\
\text { system with two } \\
\text { selling strategies: } \\
\text { retail and e-tail }\end{array}$ & $\begin{array}{l}\text { Examined the impact } \\
\text { of different return } \\
\text { policies on the } \\
\text { behaviour of supply } \\
\text { chains before and } \\
\text { after adopting a dual } \\
\text { channel. Changes in } \\
\text { profits, pricing, and } \\
\text { inventory. }\end{array}$ & & & \\
\hline
\end{tabular}

The literature that focuses on disposition has been further investigated to classify them according to the disposition method on which they focus. Figure 5 shows this further classification. 


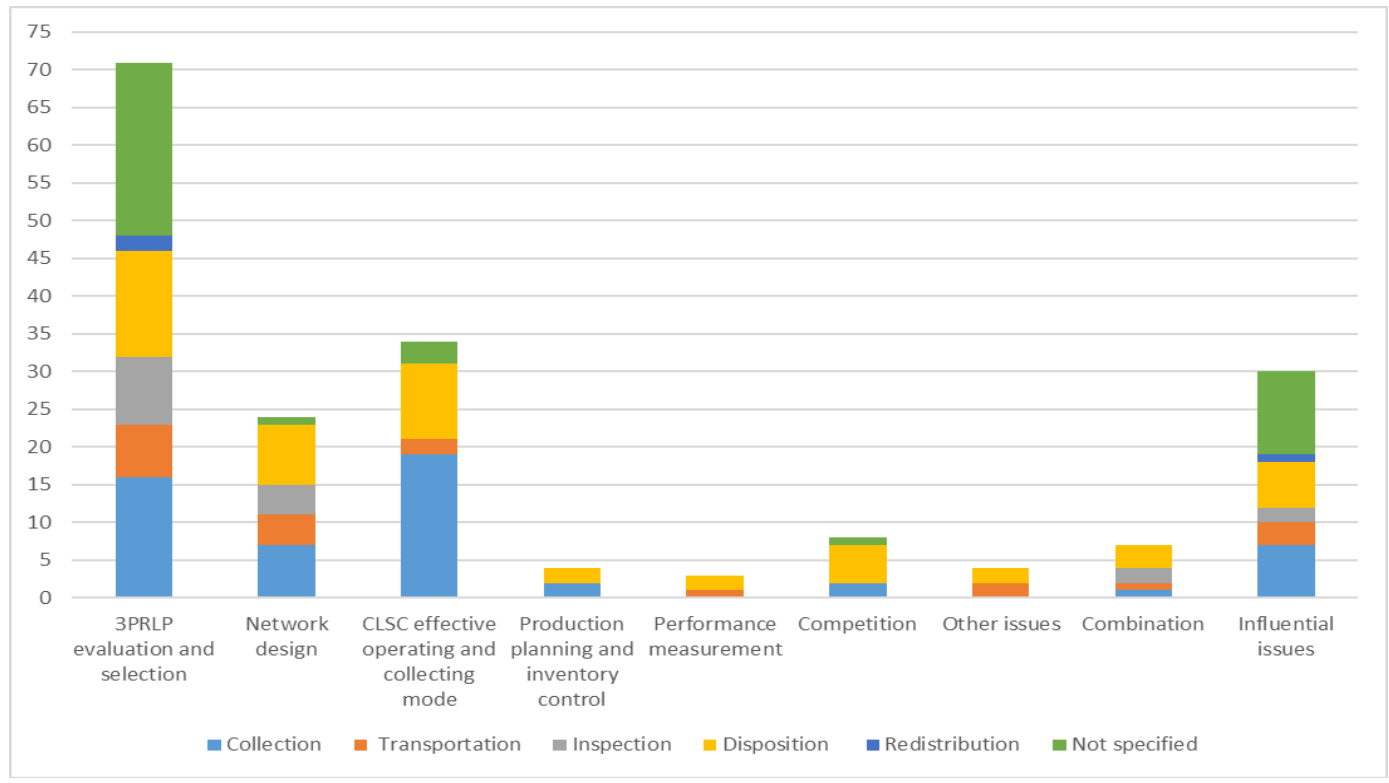

Figure 5: Classification of literature according to reverse logistics activities (see online version for colour)

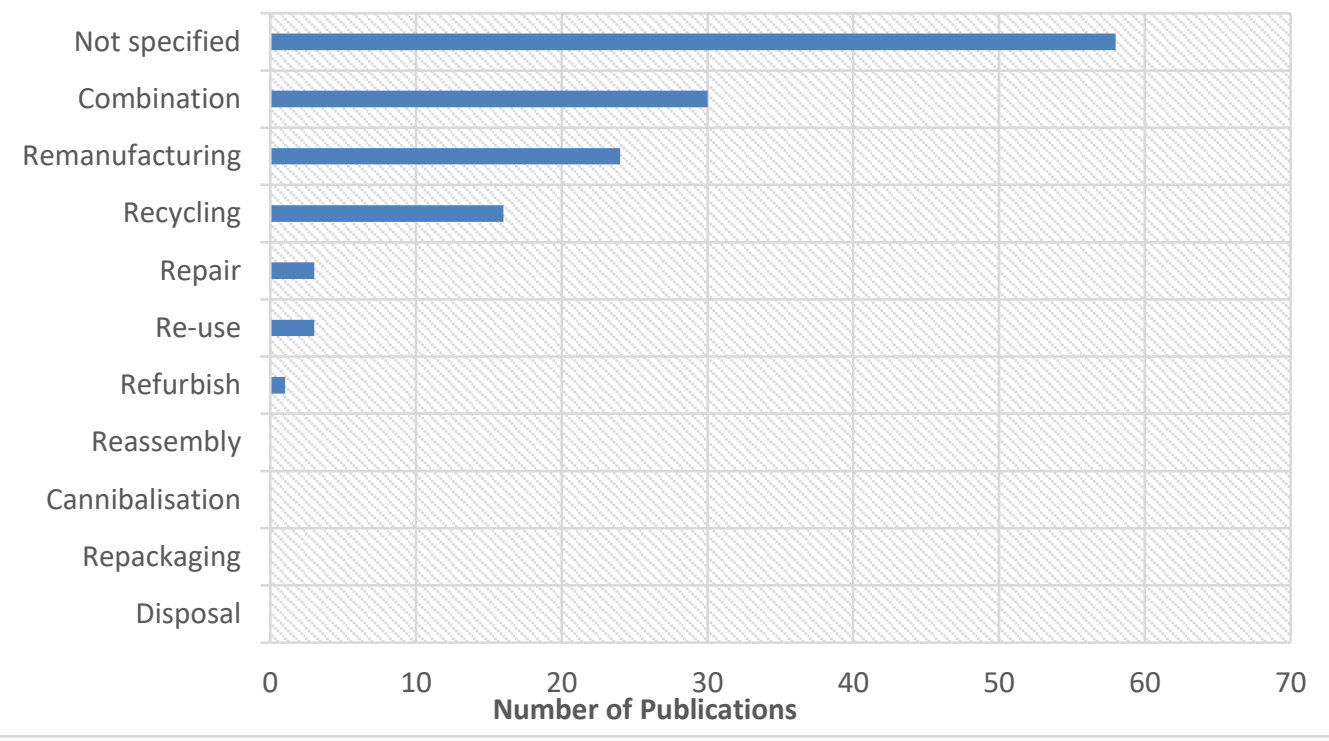

Figure 6: Disposition strategies explored by the literature on 3PRLPs

From Figure 6, most of the authors did not specify on which disposition method they focused. For those publications that specified the disposition method, most combined methods. Table 10 lists the combinations of the disposition methods listed in the literature. For both combined and stand-alone disposition methods, remanufacturing is the most looked-into disposition method. This could be because most of the publications looked into electronic products, and remanufacturing is the most common method of disposition where electronic products are concerned. Remanufacturing can be in the form of product remanufacturing, modular remanufacturing, or component/part remanufacturing. Refurbishing, repackaging, reassembly, and cannibalisation have barely been researched as standalone disposition methods, but they are combined with other methods of disposition. Again, this seems to depend on the product. Most combinations of disposition methods 
are applicable to electronic products, just as the principles of component commonality and modularity are applicable to products that can be disassembled. This shows how the literature still needs to consider other types of products with regard to reverse logistics issues.

Table 9: Summary of combination of disposition methods

\begin{tabular}{llll}
\hline Combination & $\begin{array}{l}\text { Number of } \\
\text { publications }\end{array}$ & Combination & $\begin{array}{l}\text { Number of } \\
\text { publications }\end{array}$ \\
\hline Re-use, recycle & 4 & Remanufacture, disposal & 1 \\
\hline Repair and refurbish & 3 & All methods & 1 \\
\hline Remanufacture, recycle & 7 & $\begin{array}{l}\text { Repackage, remanufacture, } \\
\text { refurbish, disposal }\end{array}$ & 1 \\
\hline Re-use, repair, recycle & 2 & Re-use, remanufacture, recycle & 4 \\
\hline $\begin{array}{l}\text { Reassembly, re-use, } \\
\text { cannibalisation, repackage }\end{array}$ & 1 & $\begin{array}{l}\text { Re-use, recycle, repair, } \\
\text { remanufacture, disposal }\end{array}$ & 3 \\
\hline Repair, repackage, refurbish & 1 & $\begin{array}{l}\text { Refurbish, cannibalisation, } \\
\text { disposal }\end{array}$ & 1 \\
\hline Upgrade, refurbish, repair & 1 & & \\
\hline
\end{tabular}

Table 9 shows that combining remanufacturing and recycling is the most common disposition method examined. Some publications (although very few) have also looked into combinations of more than two methods. This means that it is quite possible, and it can be researched.

\subsection{Reverse logistics providers and Industry 4.0}

In searching for the literature, none was found on 3PRLPs and Industry 4.0. The literature that was found mostly mentions how the concepts of Industry 4.0 might benefit the reverse logistics process. For example, Ashodian [160] mentioned such benefits of Industry 4.0 for 3PLs as connectivity of systems, equipment, devices, and facilities. This enhances every aspect of inventory and transactional management. 3PLs will also be more efficient and save costs, thus increasing competitive advantage. The instant transmission of data collected on inbound receipt of cases and pallets, and in real-time, allows for better visibility into inventory and demand patterns. However, this paper only mentions 3PLs as part of the benefits of Industry 4.0, without any reference to reverse logistics. It would be interesting to find a publication explaining how 3PRLPs use Industry 4.0 to take care of the uncertainties in reverse logistics, such as the timing, quality, and quantity of the returns.

De Man and Strandhagen [161] discussed sustainable business models and helped to identify gaps for research on how Industry 4.0 can be used to operate these models. Their main focus, however, was on the reverse logistics system and network without any consideration of 3PRLPs. Their research gaps are worth mentioning, as most reverse logistics activities are carried out by 3PRLPs, and their gaps are applicable to these 3PLs. The authors noted the gap in identifying the impact of smart factories and products on a supply chain network design to facilitate reverse logistics. From section 3.4, under network design, most of the network design problems were meant for logistics service providers, so this gap really applies to 3PRLPs as well.

Secondly, a gap was identified in how smart products can be used for production planning and control in a reverse supply chain based system. Although most production planning and inventory control issues in a supply chain are usually handled by the original equipment manufacturer, engaging 3PRLPs in a reverse logistics system might also mean including them in the planning and inventory control in the reverse chain. Because of this, it is necessary to find out how these smart products impact production planning for 3PLs as well.

\section{CONCLUSIONS AND FUTURE RESEARCH}

The literature on the entry into reverse logistics by third parties has been systematically reviewed. A total of 134 publications from peer reviewed journals up to 30 May 2018 were reviewed. The results can help researchers in the research field of reverse logistics outsourcing to identify new research interests for further publication.

The general trend is a sharp increase in publications on 3PRLPs since 2006, which shows how the field is developing - although the literature on the entry of 3PLs into reverse logistics is limited and still needs some attention. It was discovered that most articles focus on the technical issues of the 
evaluation and selection of 3PLs, while very few focused on the impact of 3PLs on the performance of the already existing supply chain. Also, most literature looked into remanufacturing as a disposition, and focused on electronic products.

The analysis of this review identified the following gaps for future research:

- Most studies looked into electronic products, which limited research to remanufacturing as a disposition method. There is a need to explore other types of products and their disposition methods. This can be extended by distinguishing between disposition methods for discrete manufacturing and those used in the processing industries.

- Most studies focused on third parties collecting and reprocessing returns. Very little literature exists for other reverse logistic activities such as inspection/testing, transportation, and distribution and sales. This is another gap that needs to be looked into in future. A third party may also perform more than one activity in reverse logistics, which presents another gap especially on how they coordinate and manage these multiple reverse logistics activities.

- It has been noted that most of the research focused on the selection of 3PRLPs and the design of reverse logistic networks. Very little attention was given to the performance measurement of reverse logistics networks once they included third parties, or the performance measurement of the third parties. This is also another gap that needs to be explored.

- In investigating collecting modes, most studies assumed a single agent collection mode, without considering competition in collection. An example of such a condition is when a third party collects at the same time as a retailer or manufacturer. This can be true for dispersed markets; and even if the market is the same, this competition has not been looked into. This also applies for other reverse logistic activities. Competition should be investigated, especially when the third parties compete with OEMs. This could provide useful managerial insights.

- Most studies using game theory for investigation focused on single-period games. It would be interesting to introduce multi-period games, or repeated games, to investigate matters of third parties in reverse logistics.

- Most articles study the entrance of third parties into reverse logistics from a financial perspective - i.e., with the main objectives of minimising costs and maximising profits. It is necessary to expand the horizon and look at other perspectives, such as the environmental perspective and the learning perspective.

- In using MCDM methodology for the selection of 3PRLPs, most studies combined popular methods into hybrids to obtain the best possible selection. Other robust multi-criteria decisionmaking methods have not been explored; and it would be interesting to see methods such as simple additive weighting (SAW) and DEMATEL to evaluate the values of each alternative. There is also a need for the expansion of hybrid methodologies in 3PRLP selection.

- It is good that the literature on network design integrates both the forward and the reverse logistics network. However, there is still a gap where network design problems are concerned. Most publications focus only on network design without combining network design with other important considerations, such as the evaluation and selection of 3PRLP.

- In designing reverse logistics networks, the main focus was on network design for the third parties on the assumption that the product can be remanufactured, which is not always true. It would be interesting to see a network design for both the OEM and the third parties, not just for the location of facilities for third parties.

- Most of the literature on selecting operating modes focuses on selecting modes for the collection of used products, followed by selecting modes for remanufacturing or recycling. There is very little literature on the selection of modes for other reverse logistics activities, such as transportation, inspection, and distribution and sales. There is also a need to explore the concept of selecting reverse channel modes from a joint perspective - that is, selecting operating channels for both collection and re-manufacturing. More options can be explored, for example, when 3P collects, inspects, and remanufactures, as opposed to when 3P collects, retailer inspects, and manufacturer recycles, in both centralised and decentralised closed loop supply chains. There is also a need to increase the literature, as 17 publications are not enough to derive conclusions on the topic.

- The use of other methods, such as heuristics and algorithms, in optimising reverse logistic channels with third parties is another issue that needs to be looked into in future.

- None of the literature included the concept of Industry 4.0 and its impact on the main decisions about the employment of 3PRLPs. This shows how young the topic still is; and there is still a 
need to investigate the impact of Industry 4.0 on issues such as 3PRLPS evaluation, network design, production planning, and inventory control.

- It will be interesting to see how incorporating Industry 4.0 in a reverse supply chain with a 3PRLP will change the system, both negatively and positively, based on empirical research.

In conclusion, research on the entry of 3PLs into reverse logistics is still limited, with a considerable number of gaps that need to be explored. Most disposition strategies have not been looked into, while most research has focused on the selection of 3PLs. The literature on its own is still too small to be representative of the topic, and more exploratory and empirical research needs to be carried out on this issue.

\section{REFERENCES}

[1] Robinson, A. 2014. History of Reverse Logistics is at the Core of The Stories of War, Retail, eCommerce, and Automotive Aftermarket, https://cerasis.com/2014/02/20/history-of-reverse-logistics/.

[2] Le Blanc, H. M. 2006. Closing loops in supply chain management: designing reverse supply chains for endof-life vehicles, University of Tilburg.

[3] Thierry, M., Salomon, M., Van Nunen, J., \& Van Wassenhove, L.N. 1995. Strategic Issues in Product Recovery Management, California Management Review, vol. 37.

[4] Atasu Atalay, V. W. L. N. 2010. Environmental Legislation on Product take back and recovery, in Closed Loop Supply Chains: New Improvements to improve the sustainability of business practices, S. G. C. Ferguson Mark E., Eds. CRC Press: Taylor and Francis Group.

[5] Aguezzoul, A. 2007. The Third Party Logistics Selection: A Review of Literature, in International Logistics and Supply Chain Congress, 2007, p. 7.

[6] Craig, T. 2003. http://www.ltdmgmt.com/, 4PL versus 3PL-A business process outsourcing option for international supply chain management.

[7] Ye, T. \& Zhenhua, Y. 2014. Reverse logistics network: A literature review, Journal of Chemical and Pharmaceutical Research, vol. 6, no. 7, pp. 1916-1921.

[8] Agrawal, S., Singh, R. K., \& Murtaza, Q. 2015. A literature review and perspectives in reverse logistics, Resources, Conservation \& Recycling, vol. 97, pp. 76-92.

[9] Rezaei, J. 2015. A systematic review of multi-criteria decision-making applications in reverse logistics, Procedia Transportation Research, vol. 10, pp. 766-776.

[10] Govindan, K., Soleimani, H., \& Kannan, D. 2015. Reverse logistics and closed-loop supply chain: A comprehensive review to explore the future, European Journal of Operational Research, vol. 240, no. 3, pp. 603-626.

[11] Guo, S., Shen, B., Choi, T. M., \& Jung, S. 2017. A review on supply chain contracts in reverse logistics: Supply chain structures and channel leaderships, Journal of Cleaner Production, vol. 144, pp. 387-402.

[12] Bazan, E., Jaber, M. Y., \& Zanoni, S. 2016. A review of mathematical inventory models for reverse logistics and the future of its modeling: An environmental perspective, Applied Mathematical Modelling, vol. 40, no. 5-6, pp. 4151-4178.

[13] Denyer, D. \& Tranfield, D. 2009. Producing a Systematic Review, in The SAGE Handbook of Organisational Research Methods, D. Buchanan and A. Bryman, Eds. SAGE Publications Ltd, p. 776.

[14] Thomé, A. M. T., Scavarda, L. F., \& Scavarda, A. J. 2016. Conducting systematic literature review in operations management, Production Planning \& Control, vol. 27, no. 5, pp. 408-420.

[15] Kafa, N., Hani, Y., \& El Mhamedi, A. 2018. Evaluating and selecting partners in sustainable supply chain network: a comparative analysis of combined fuzzy multi-criteria approaches, Opsearch, vol. 55, no. 1 , pp. 14-49.

[16] Sabtu, M. I., Saibani, N., Ramli, R., \& Ab Rahman, M. N. 2015. Multi-criteria decision making for reverse logistic contractor selection in e-waste recycling industry using polytomous rasch model, Jurnal Teknologi, vol. 77, no. 27, pp. 119-125.

[17] Venkatesh, V. G., Bhattacharya, S., Sethi, M., \& Dua, S. 2015. Performance Measurement of sustainable reverse logistics provider by Data Envelope Analysis: Case of an Indian Apparel group, International Journal of Automation and Logistics, vol. 1, no. 3.

[18] Tavana, M., Zareinejad, M.,Santos-Artega, F.J., Kaviani, M.A., \& Amin, M. 2016. A conceptual Analytic Network model for evaluating and selecting Third Party Reverse Logistics Providers, International Journal of Advanced Manufacturing Technology, vol. 86, pp. 1705-1721.

[19] Mavi, R. K., Goh, M., \& Zarbakhshnia, N. 2017. Sustainable third-party reverse logistic provider selection with fuzzy SWARA and fuzzy MOORA in plastic industry, The International Journal of Advanced Manufacturing Technology, vol.91,pp.2401-2418.

[20] Zarbakhshnia, N., Soleimani, H., \& Ghaderi, H. 2018. Sustainable third-party reverse logistics provider evaluation and selection using fuzzy SWARA and developed fuzzy COPRAS in the presence of risk criteria, Applied Soft Computing, vol. 65, pp. 307-319.

[21] Prakash, C. \& Barua, M. K. 2016. An analysis of integrated robust hybrid model for third-party reverse logistics partner selection under fuzzy environment, Resources, Conservation \& Recycling, vol. 108, pp. 63-81.

[22] Meade, L. \& Sarkis, J. 2002. A conceptual model for selecting and evaluating third-party reverse logistics providers, Supply Chain Management: An International Journal, vol. 7, no. 5, pp. 283-295. 
[23] Efendigil, T., Onut, S., \& Kongar, E. 2008. A holistic approach for selecting a third-party reverse logistics provider in the presence of vagueness, Computers \& Industrial Engineering, vol. 54, pp. 269-287.

[24] Kannan, G., Pokharel, S., \& Kumar, P. S. 2009. A hybrid approach using ISM and fuzzy TOPSIS for the selection of reverse logistics provider, Resources, Conservation and Recycling, vol. 54, no. 1, pp. 28-36.

[25] Kannan, G., Murugesan, P., \& Haq, A. N. 2009. 3PRLP's selection using an integrated analytic hierarchy process and linear programming, International Journal of Services Technology and Management, vol. 12, no. 1, p. 61.

[26] Govindan, K. 2009. Fuzzy Approach for the selection of 3PRLP, Asia-Pacific Journal of Marketing and Logistics, vol. 21, no. 3, pp. 397-416.

[27] Govindan, K., Pokharel, S., \& Sasikumar, P. 2009. A hybrid approach using ISM and fuzzy TOPSIS for the selection of reverse logistics provider, Resources, Conservation and Recycling, vol. 54, pp. 28-36.

[28] Saen, R. F. 2009. A Mathematical Model for Selecting Third-Party Reverse Logistics Providers, International Journal of Procurement Management.

[29] Murugesan, P. \& Noorul Haq, A. 2010. A decision-making framework for the selection of third-party reverse logistics provider, International Journal of Services, Economics and Management, vol. 2, no. 3-4, pp. 350-370.

[30] Saen, R. F. 2010. A New Look at Selecting Third-Party Reverse Logistics Providers, International Journal of Information Systems and Supply Chain Management, vol. 3, no. 1, pp. 58-67.

[31] Cheng, Y. \& Lee, F. 2010. Outsourcing reverse logistics of high-tech manufacturing firms by using a systematic decision-making approach : TFT-LCD sector in Taiwan, Industrial Marketing Management, vol. 39, no. 7, pp. 1111-1119.

[32] Govindan, K. \& Murugesan, P. 2011. Selection of 3PRLP using fuzzy extent analysis, Benchmarking: An International Journal, vol. 18, no. 1, pp. 149-167.

[33] Azadi, M. \& Saen, R. F. 2011. Developing an Output-Oriented Super Slacks-Based Measure Model with an Application to Third-Party Reverse Logistics Providers, Journal of Multi-Criteria Decision Analysis, vol. 18, pp. 267-277.

[34] Azadi, M. \& Farzipoor, R. 2011. A new chance-constrained data envelopment analysis for selecting thirdparty reverse logistics providers in the existence of dual-role factors, Expert Systems With Applications, vol. 38, no. 10, pp. 12231-12236.

[35] Saen, R. F. 2011. A decision model for selecting 3PRLPs in the presence of both dual role factors and imprecise data, Asia-Pacific Journal of Operational Research, vol. 28, no. 2, pp. 239-254.

[36] Ravi, V. 2011. Selection of third-party reverse logistics providers for End-of-Life computers using TOPSISAHP based approach, International Journal of Logistics Systems and Management, vol. 11, no. 1, p. 24.

[37] Kara, S. 2011. Evaluation of outsourcing companies of waste electrical and electronic equipment recycling, International Journal of Environmental Science and Technology, vol. 8, no. 2, pp. 291-304.

[38] Azadi, M., Zoroufchi, K. H., \& Saen, R. F. 2012. A combination of Russell model and neutral DEA for 3PL provider selection, International Journal of Productivity and Quality Management, vol. 10, no. 1, p. 25.

[39] Govindan, K., Palaniappan, M., Zhu, Q., \& Kannan, D. 2012. Analysis of third party reverse logistics provider using interpretive structural modeling, International Journal of Production Economics, vol. 140, no. 1, pp. 204-211.

[40] Zhou, Z. 2012. Research on selection of third-party reverse logistics supplier based on fuzzy analytic hierarchy process method, Advanced Materials Research, vol. 472-475, pp. 3395-3398.

[41] Jihen, J., El Mhamedi, A., \& Chabchoub, H. 2012. A fuzzy PROMETHEE II method for the selection of reverse logistics provider, International Journal of Enterprise Network Management, vol. 5, no. 3, p. 304.

[42] Zhang, R., Zhang, H., \& Liu, B. 2012. Selection of Reverse Logistics services for product with fuzzy comprehensive evaluation method, Grey Systems, Theory and Applications, vol. 2, no. 2, pp. 207-216.

[43] Xi, F. \& Wen-qi, J. 2012. Study on Scrap Automobile Manufacturers Reverse Logistics Partners Based on Evaluation Engineering, Systems Engineering Procedia, vol. 5, pp. 213-221.

[44] Zareinejad, M. \& Javanmard, H. 2013. Evaluation and selection of a third-party reverse logistics provider using ANP and IFG-MCDM methodology, Life Science Journal, vol. 1, no. 6s.

[45] Chen, K., Yu, X., \& Yang, L. 2013. GI-TOPSIS based on combinational weight determination and its application to selection of reverse logistics service providers, Journal of Grey System, vol. 25, no. 3, pp. 16-33.

[46] Govindan, K., Sarkis, J., \& Palaniappan, M. 2013. An Analytic Network Process based Multicriteria Decision Making model for a reverse supply chain, International Journal of Advanced Manufacturing Technology, vol. 68, no. 1-4, pp. 863-880.

[47] Azadi, M. \& Saen, R. F. 2013. Developing a Chance-Constrained Free Disposable Hull Model for Selecting Third-Party Reverse Logistics Providers, International Journal of Operations Research and Information Systems, vol. 4, no. 4, pp. 96-113.

[48] Gong, Y.-X., Song, J.-D., Peng, Y.-G., Tian, Y., \& Zheng, S.-Q. 2014. Hybrid intelligent approach for the selection of third-party reverse logistics provider under uncertainty, Journal of Donghua University (English Edition), vol. 31, no. 4, pp. 484-492.

[49] Tajik, G., Azadnia, A. H., Ma'aram, A. B., \& Hassan, S. A. H. S. 2014. A Hybrid Fuzzy MCDM Approach for Sustainable Third-Party Reverse Logistics Provider Selection, Advanced Materials Research, vol. 845, pp. 521-526.

[50] Kafa, N., Hani, Y., \& El Mhamedi, A. 2014. A Fuzzy Multi Criteria Approach for Evaluating Sustainability Performance of Third - Party Reverse Logistics Providers, IFIP Advances in Information and Communication Technology, vol. 439, no. PART 2, pp. 270-277. 
[51] Jayant, A., Gupta, P., Garg, S. K., \& Khan, M. 2014. TOPSIS-AHP Based Approach for Selection of Reverse Logistics Service Provider: A Case Study of Mobile Phone Industry, Procedia Engineering, vol. 97, pp. 21472156.

[52] Senthil, S., Srirangacharyulu, B., \& Ramesh, A. 2014. A robust hybrid multi-criteria decision making methodology for contractor evaluation and selection in third-party reverse logistics, Expert Systems With Applications, vol. 41, no. 1, pp. 50-58.

[53] Choudhary, D., Madaan, J., \& Narain, R. 2014. An Integrated Decision Model for Selection of Third Party Recovery Facilitator ( 3PRF ) for Product Recovery Operations, Journal of Operations and Supply Chain Management, vol. 7, no. 2.

[54] Sahu, N. K., Sahu, A. K., \& Sahu, A. K. 2015. Appraisement and benchmarking of third-party logistic service provider by exploration of risk-based approach, Cogent Business \& Management, vol. 2, no. 1, pp. $1-22$.

[55] Momeni, E., Azadi, M., \& Saen, R. F. 2015. Measuring the efficiency of third party reverse logistics provider in supply chain by multi objective additive network DEA model, International Journal of Shipping and Transport Logistics, vol. 7, no. 1, p. 21.

[56] Guarnieri, P., Amorim, V., \& Seido, M. 2015. The challenge of selecting and evaluating third-party reverse logistics providers in a multicriteria perspective: a Brazilian case, Journal of Cleaner Production, vol. 96, pp. 209-219.

[57] Khodaverdi, R. \& Petrudi, S. H. H. 2015. A grey-based decision-making approach for selecting a reverse logistics provider in a closed loop supply chain, International Journal of Management and Decision Making, vol. 14, no. 1.

[58] Tavana, M., Zareinejad, M., \& Santos-Arteaga, F. J. 2016. An intuitionistic fuzzy-grey superiority and inferiority ranking method for third-party reverse logistics provider selection, International Journal of Systems Science: Operations \& Logistics, vol. 5, no 2, pp. 175-194.

[59] Prakash, C. \& Barua, M. K. 2016. A combined MCDM approach for evaluation and selection of third-party reverse logistics partner for Indian electronics industry, Sustainable Production and Consumption, vol. 7, no. March, pp. 66-78.

[60] Tavana, M., Zareinejad, M., \& Di Caprio, D. 2016. An integrated intuitionistic fuzzy AHP and SWOT method for outsourcing reverse logistics, Applied Soft Computing Journal, vol. 40, pp. 544-557.

[61] Saaty, T. L. 1977. A scaling method for priorities in hierarchical structures, Journal of Mathematical Psychology, vol. 15, no. 3, pp. 234-281.

[62] Saaty, T. L. 1996. Decision making with dependence and feedback: The analytic network process. Pittsburgh, PA: RWS Publications. Samvedi, A., Jain, V., \& Chan, FTS (2012). An integrated approach for machine tool selection using fuzzy analytical hierarchy process and grey relational analysis. International Journal of Production Research, vol. 50, no. 12.

[63] Hwang, C. L. \& Yoon, K. 1981. Multiple attributes decision making methods and applications. Berlin: Springer.

[64] Charnes, A., Cooper, W. W., \& Rhodes, E. L. 1978. Measuring the Efficiency of Decision Making Units, European Journal of Operational Research, vol. 2, pp. 429-444.

[65] Pakkar, M. S. 2016. An integrated approach to grey relational analysis, analytic hierarchy process and data envelopment analysis, Journal of Centrum Cathedra: The Business and Economics Research Journal, vol. 9, no. 1, pp. 71-86.

[66] Deng, J. 1982. The Control Problems of Grey Systems, Systems \& Control Letters.

[67] Kumar, J. \& Roy, N. 2010. A Hybrid Method for Vendor Selection using Neural Network, International Journal of Computer Applications, vol. 11, no. 12, pp. 35-40.

[68] Fleischmann, M. 2000. Quantitative Models for Reverse Logistics. Rotterdam: Erasmus University.

[69] Karakayali, I., Emir-Farinas, H., \& Akcali, E. 2007. An analysis of decentralized collection and processing of end-of-life products, Journal of Operations Management, vol. 25, no. 6, pp. 1161-1183.

[70] Chiu, Y., Lin, P.-C., \& Hsu, H.-H. 2011. Considering Third Party Logistics Providers in Reverse Logistics, Journal of Chinese Institute of Industrial Engineers, vol. 28, no. 7, pp. 512-520.

[71] Spicer, A. J. \& Johnson, M. R. 2004. Third-party demanufacturing as a solution for extended producer responsibility, Journal of Cleaner Production, vol. 12, pp. 37-45.

[72] Savaskan, R. C., Bhattacharya, S., \& Van Wassenhove, L. N. 2004. Closed Loop Supply Chain models with product remanufacturing, Management Science, vol. 50, no. 2, pp. 239-252.

[73] Kumar, S. \& Malegeant, P. 2006. Strategic alliance in a closed-loop supply chain, a case of manufacturer and eco-non-profit organization, Technovation, vol. 26, no. 10, pp. 1127-1135.

[74] Huang, X. Y., Yan, N. N., \& Qiu, R. Z. 2009. Dynamic models of closed-loop supply chain and robust $\mathrm{H}^{\infty}$ control strategies, International Journal of Production Research, vol. 47, no. 9, pp. 2279-2300.

[75] Sasikumar, P. \& Haq, A. N. 2010. A Multi Criteria Decision Making Methodology for the selecion of Reverse Logistics operating, International Journal of Enterprise Network Management, vol. 4, no. 1.

[76] Kaya, 0. 2010. Incentive and production decisions for remanufacturing operations, European Journal of Operational Research, vol. 201, pp. 442-453.

[77] Yan, N. \& Sun, B.-W. 2012. Optimal Stackelberg strategies for Closed Loop Supply Chain with Third-Party Reverse Logistics, Asia-Pacific Journal of Operational Research, vol. 29, no. 5.

[78] Zhang, J. \& Chen, C. 2012. A Dynamic Game Model of Reverse Logistics for End-of-Life Electronic Products Based on Complete Information, Advanced Materials Research, vol. 472-475, pp. 3399-3404.

[79] Senthil, S., Srirangacharyulu, B., \& Ramesh, A. 2012. A decision making methodology for the selection of reverse logistics operating channels, Procedia Engineering, vol. 38, pp. 418-428. 
[80] Hong, I. \& Yeh, J. 2012. Modeling closed-loop supply chains in the electronics industry: A retailer collection application, Transportation Research Part E, vol. 48, no. 4, pp. 817-829.

[81] Ma, W. M., Zhao, Z., \& Ke, H. 2013. Dual-channel closed-loop supply chain with government consumptionsubsidy, European Journal of Operational Research, vol. 226, no. 2, pp. 221-227.

[82] Choi, T. M., Li, Y., \& Xu, L. 2013. Channel leadership, performance and coordination in closed loop supply chains, International Journal of Production Economics, vol. 146, no. 1, pp. 371-380.

[83] Chuang, C. H., Wang, C. X., \& Zhao, Y. 2014. Closed-loop supply chain models for a high-tech product under alternative reverse channel and collection cost structures, International Journal of Production Economics, vol. 156, pp. 108-123.

[84] Hong, X., Xu, L., Du, P., \& Wang, W. 2015. Joint Advertising, Pricing and Collection decisions in a closed loop supply chain, International Journal of Production Economics, vol. 167, pp. 12-22.

[85] Jindal, A. \& Sangwan, K. S. 2015. Evaluation of collection methods in reverse logistics by using fuzzy mathematics, Benchmarking: An International Journal, vol. 22, no. 3, pp. 393-410.

[86] Abdulrahman, M. D., Subramanian, N., Liu, C., \& Shu, C. 2015. Viability of remanufacturing practice: a strategic decision making framework for Chinese auto-parts companies, Journal of Cleaner Production, vol. 105, pp. 311-323.

[87] Shi, Y., Nie, J., \& Qu, T. 2015. Choosing Reverse channels under collection responsibility sharing in a closed loop supply chain with re-manufacturing, Journal of Intelligent Manufactiring, vol. 26, no. 2, pp. 387-402.

[88] Hong, X., Zhang, H., Zhong, Q., \& Liu, L. 2016. Optimal decisions of a hybrid manufacturing Remanufacturing system within a closed-loop supply chain, European Journal of Industrial Engineering, vol. 10, no. 1, pp. 21-50.

[89] Yi, P., Huang, M., Guo, L., \& Shi, T. 2016. Dual recycling channel decision in retailer oriented closed-loop supply chain for construction machinery remanufacturing, Journal of Cleaner Production, vol. 137, pp. 1393-1405.

[90] Aydin, R., Kwong, C. K., \& Ji, P. 2016. Coordination of the closed-loop supply chain for product line design with consideration of remanufactured products, Journal of Cleaner Production, vol. 114, pp. 286-298.

[91] Zheng, J. \& Wu, J. 2016. Research on closed loop supply chain with the Third Party Recycler based on consumer preference, Journal of Service Science and Management, no. 9, pp. 175-181.

[92] Miao, S., Wang, T., \& Chen, D. 2017. System dynamics research of remanufacturing closed-loop supply chain dominated by the third party, Waste Management and Research, vol. 35, no. 4, pp. 379-386.

[93] Kong, L., Liu, Z., Pan, Y., Xie, J., \& Yng, G. 2017. Pricing and service decision of dual-channel operations in an $\mathrm{O} 20$ closed-loop supply chain, Industrial Management and Data Systems vol. 117, no. 8, pp.15671588

[94] Giri, B. C., Chakraborty, A., \& Maiti, T. 2017. Pricing and return product collection decisions in a closedloop supply chain with dual-channel in both forward and reverse logistics, Journal of Manufacturing Systems, vol. 42, pp. 104-123.

[95] Li, H., Wang, C., Xu, L., \& Ou, W. 2017. Pricing, carbon emission reduction, collection decision, and coordination in a low-carbon closed-loop supply chain, Journal of Renewable and Sustainable Energy, vol. 9 , no. 6.

[96] Krumwiede, D. W. \& Sheu, C. 2002. A model for reverse logistics entry by third-party providers, International Journal of Management Science, vol. 30, pp. 325-333.

[97] Ordoobadi, S. M. 2007. Outsourcing reverse logistics and remanufacturing functions: a conceptual strategic model, Management Research News, vol. 32, no. 9, pp. 831-845.

[98] Shaharudin, M. R., Zailani, S., \& Ismail, M. 2014. Third party logistics orchestrator role in reverse logistics and closed-loop supply chains, International Journal of Logistics Systems and Management, vol. 18, no. 2, p. 200.

[99] Shaharudin, M. R., Zailani, S., \& Muhazir, I. 2015. Third party logistics strategic orientation towards the reverse logistics service offerings, International Journal of Management Practice, vol. 8, no. 4.

[100] Li, Y., Kannan, D., Garg, K., Gupta, S., Gandhi, K., \& Jha, P. C. 2018. Business orientation policy and process analysis evaluation for establishing third party providers of reverse logistics services, Journal of Cleaner Production, vol. 182, pp. 1033-1047.

[101] Verstrepen, S., Cruijssen, F., De Brito, M. P., \& Dullaert, W. 2007. An Exploratory Analysis of Reverse Logistics in Flanders, European Journal of Transport and Infrastructure Research, vol. 4, no. 4, pp. 301316.

[102] Klapalová, A. 2012. Reverse logistics and 3PL in the Czech Republic, Acta Universitatis Agriculturae et Silviculturae Mendelianae Brunensis, vol. 60, no. 7, pp. 163-170.

[103] Cruz Netro, Z. G., Medina Álvarez, J. E., Cartas Carrillo, A., \& Garza Flores, R. 2016. Solid waste management in Mexico's offshore platform construction: determining potential supply for a reverse logistics process, NETNOMICS: Economic Research and Electronic Networking, vol. 17, no. 1, pp. 71-94.

[104] Serrato, M. A.Ryan, S.A.,Gayta'n, J. 2007, A Markov decision model to evaluate outsourcing in reverse logistics, International Journal of Production Research, vol. 45, no. 18-19, pp. 4289-4315.

[105] Guo, T. \& Li, X. 2008. Outsourcing or self-operation decision making in reverse logistics based on analytic network process, Systems Engineering and Electronics, vol. 30, no. 6, pp. 1181-1185.

[106] Logozar, K. 2008. Outsourcing Reverse Logistics, Zagreb International Review of Economics \& Business, vol. 11 , no. 2, p. 35.

[107] Zhang, N. \& Sun, B. 2008. Key Factors for the Selection of Logistics Service Provider in a Closed-Loop Supply Chain, 2008 4th International Conference on Wireless Communications, Networking and Mobile Computing , pp. 1-4. 
[108] Martin, P., Guide, V. D. R., \& Craighead, C. W. 2010. Supply chain sourcing in remanufacturing operations: An empirical investigation of remake versus buy, Decision Sciences, vol. 41, no. 2, pp. 301-324.

[109] Nikolaidis, Y. 2009. A modelling framework for the acquisition and remanufacturing of used products, International Journal of Sustainable Engineering, vol. 2, no. 3, pp. 154-170.

[110] Meng, X. R. 2010. The Risk Analysis of Reverse Logistics outsourcing based on the fuzzy Comprehensive Analysis Method, Advanced Materials Research, vol. 108-111, pp. 1113-1118.

[111] Lambert, S., Riopel, D., \& Abdul-Kader, W. 2011. A reverse logistics decisions conceptual framework, Computers \& Industrial Engineering, vol. 61, no. 3, pp. 561-581.

[112] Murali, S., Pugazhendhi, S., \& Ganesh, K. 2011. Role of third party logistics providers in reverse logistics, International Journal of Operations System and Human Resource Management, vol. 1, no. 1-2, pp. 77-84.

[113] Sharif, A. M., Irani, Z., \& Love, P. E. D. 2012. Evaluating reverse third-party logistics operations using semi fuzzy approach, International Journal of Production Research, vol. 50, no. 9 Special Issue (SI), pp. 2515-2532.

[114] Janusz, G. \& Kot, S. 2010. Business Relations in Reverse Logistics Outsourcing, Economic Analysis, vol. 43, no. 1-2, pp. 99-107.

[115] Krikke, H., Hofenk, D., \& Wang, Y. 2013. Revealing an invisible giant: A comprehensive survey into return practices within original (closed-loop) supply chains, Resources, Conservation \& Recycling, vol. 73, pp. 239-250.

[116] Badenhorst, A. \& Van Zyl, C. 2015. Finding theoretical evidence to justify the outsourcing of reverse logistics, Journal of Contemporary Management, vol. 12, pp. 144-163.

[117] Agrawal, S., Singh, R. K., \& Murtaza, Q. 2016. Outsourcing decisions in reverse logistics: Sustainable balanced scorecard and graph theoretic approach, Resources, Conservation and Recycling, vol. 108, pp. 41-53.

[118] Lee, D.-H., Bian, W., \& Dong, M. 2007. Multiobjective model and solution method for integrated forward and reverse logistics nework design for third party logistics providers, Transportation Research Record, vol. 232, pp. 43-52.

[119] Lee, D.-H., Bian, W., \& Dong, M. 2007. Multiproduct distribution network design for third party logistics providers with reverse logistics operations, Transportation Research Record, no. 2008, pp. 26-33.

[120] Ko, H. J. \& Evans, G. W. 2007. A genetic algorithm-based heuristic for the dynamic integrated forward / reverse logistics network for 3PLs, Computers and Operation Research, vol. 34, pp. 346-366.

[121] Hyangsook, L., Zhang, T., \& Boile, M. 2013. Designing an Integrated logistics network in a supply chain system, KSCE Journal of Civil Engineering, vol. 17, no. 4, pp. 806-814.

[122] Kusumastuti, R. D., Piplani, R., \& Hian Lim, G. 2008. Redesigning closed-loop service network at a computer manufacturer: A case study, International Journal of Production Economics, vol. 111, no. 2, pp. 244-260.

[123] Min, H. \& Ko, H. 2008. The dynamic design of a reverse logistics network from the perspective of thirdparty logistics service providers, International Journal of Production Economics, vol. 113, pp. 176-192.

[124] Hao, Q., Xu, X., Liu, Q., \& Liu, X. 2013. Research on optimizing reverse logistics network of waste copper recycling, Advanced Materials Research, vol. 798, pp. 967-970.

[125] Lin, W.-T., Lee, H.-C., \& Lee, Y.-H. 2009. A decision making model for Reverse Logistics Service Providers in determining robust optimal processing quanities of returned products, Journal of Chinese Institute of Industrial Engineers, vol. 26, no. 5, pp. 397-410.

[126] Das, K. \& Chowdhury, A. H. 2012. Designing a reverse logistics network for optimal collection, recovery and quality-based product-mix planning, International Journal of Production Economics, vol. 135, no. 1, pp. 209-221.

[127] Suyabatmaz, A. C., Altekin, F. T., \& Sahin, G. 2014. Hybrid simulation-analytical modeling approaches for the reverse logistics network design of a third-party logistics provider, Computers \& Industrial Engineering, vol. 70, pp. 74-89.

[128] Mahmoudzadeh, M., Mansour, S., \& Karimi, B. 2013. To develop a third-party reverse logistics network for end-of-life vehicles in Iran, Resources, Conservation \& Recycling, vol. 78, pp. 1-14.

[129] Alshamsi, A. \& Diabat, A. 2017. A Genetic Algorithm for Reverse Logistics network design: A case study from the GCC, Journal of Cleaner Production, vol. 151, pp. 652-669.

[130] Kannan, D., Garg, K., Jha, P. C., \& Diabat, A. 2017. Integrating disassembly line balancing in the planning of a reverse logistics network from the perspective of a third party provider, Annals of Operations Research, vol. 253, no. 1, pp. 353-376.

[131] Li, R. \& Huang, M. 2017. Reliable reverse network design of third-party logistics under proactive attacks, Computer Integrated Manufacturing Systems, CIMS, vol. 23, no. 9, pp. 1992-2002.

[132] Yu, H. \& Solvang, W. D. 2016. A general reverse logistics network design model for product reuse and recycling with environmental considerations, International Journal of Advanced Manufacturing Technology, vol. 87, no. 9-12, pp. 2693-2711.

[133] Darbari, J. D., Kannan, D., Agarwal, V., \& Jha, P. C. 2017. Fuzzy criteria programming approach for optimising the TBL performance of closed loop supply chain network design problem, Annals of Operations Research, pp. 1-46.

[134] Ferguson, M. E. \& Toktay, L. B. 2006. The Effect of Competition on Recovery Strategies, Production and Operations Management, vol. 15, no. 3, pp. 351-368.

[135] Bulmus, S. C., Zhu, S. X., \& Teunter, R. 2014. Competition for cores in remanufacturing, European Journal of Operational Research, vol. 233, no. 1, pp. 105-113.

[136] Webster, S. \& Mitra, S. 2007. Competitive strategy in remanufacturing and the impact of take-back laws, Journal of Operations Management, vol. 25, pp. 1123-1140. 
[137] Mitra, S. \& Webster, S. 2008. Competition in remanufacturing and the effects of government subsidies, International Journal of Production Economics, vol. 111, pp. 287-298.

[138] Orsdemir, A., Kemahhoglu-Ziya, E., \& Parlakturk, A. K. 2014. Competitive Quality Choice and Remanufacturing, Productions and Operaions Management, vol. 23, no. 1, pp. 48-64.

[139] Neely, A., Gregory, M., \& Platts, K. 1995. Performance measurement system design: A Literature Review and Research Agenda, International Journal of Operation \& Production Management, vol. 15, no. 4, pp. 80-116.

[140] Bai, C. \& Sarkis, J. 2013. Flexibility in reverse logistics: a framework and evaluation approach, Journal of Cleaner Production, vol. 47, pp. 306-318.

[141] Hosoda, T., Altekin, F. T., \& Sahin, G. 2015. The impact of information sharing, random yield correlation and lead times in closed loop suply chains, European Journal of Operational Research, vol. 246, pp. 827836.

[142] He, S., Yuan, X., \& Zhang, X. 2016. The Government's environment policy index impact on recycler behavior in electronic products closed-loop supply chain, Discrete Dynamics in Nature and Society, vol. 2016.

[143] Agrawal, A. \& Choudhary, V. 2014. Reverse Logistics: Performance Measures and their effect in product lifecycle, International Journal Of Core Engineering \& Management, vol. 1, no. 2, pp. 14-22.

[144] Lee, H. L., Padmanabhan, V., \& Whang, S. 1997. Information Distortion in a Supply Chain: The Bullwhip Effect, Management Science, vol. 43, no. 4, pp. 546-558.

[145] Adenso-Diaz, B., Moreno, P. P., Gutierrez, E., \& Lozano, S. 2012. An analysis of the main factors affecting bullwhip in reverse supply chains, International Journal of Production Economics, vol. 135, pp. 917-928.

[146] Galbreth, M. R. \& Blackburn, J. D. 2006. Optimal acquisition and sorting policies for remanufacturing, Production and Operations Mangement, vol. 15, no. 3, pp. 384-392.

[147] Chung, S., Wee, H., \& Yang, P. 2008. Optimal Policy for Closed Loop Supply Chain inventory system with remanufacturing, Mathematical and Computer Modelling, vol. 48, pp. 867-881.

[148] Jung, K. S., Dawande, M., Geismar, H.N., Sriskandarajah, C. 2016. Supply planning models for a remanufacturer under just-in-time manufacturing environment with reverse logistics, Annals of Operations Research, vol. 240, pp. 533-581.

[149] Kafa, N., Hani, Y., \& El Mhamedi, A. 2015. An integrated sustainable partner selection approach with closed-loop supply chain network configuration, IFAC-Papers OnLine, vol. 28, no. 3, pp. 1840-1845.

[150] Wu, C. \& Barnes, D. 2016. Partner selection for reverse logistics centres in green supply chains: a fuzzy artificial immune optimisation approach, Production Planning and Control, vol. 27, no. 16, pp. 1356-1372.

[151] Govindan, K., Agarwal, V., Darbari, J. D., \& Jha, P. C. 2017. An integrated decision making model for the selection of sustainable forward and reverse logistic providers, Annals of Operations Research, pp. 144.

[152] Li, Y., Guo, H., \& Zhang, Y. 2017. An integrated location-inventory problem in a closed-loop supply chain with third-party logistics, International Journal of Production Research, vol. 7543, pp. 1-20.

[153] Huang, M., Song, M., Lee, L. H., \& Ching, W. K. 2013. Analysis for strategy of closed-loop supply chain with dual recycling channel, International Journal of Production Economics, vol. 144, no. 2, pp. 510-520.

[154] Agrawal, S., Singh, R. K., \& Murtaza, Q. 2016. Outsourcing decisions in reverse logistics: Sustainable balanced scorecard and graph theoretic approach, Resources, Conservation \& Recycling, vol. 108, pp. 4153.

[155] Ding, X. H., Zhang, S. X., Zhang, Y. Y., \& Zhong, W. Z. 2010. Pattern of the 3rd Party Reverse Logistics System in Ecological Industrial Park, Advanced Materials Research, vol. 171-172, pp. 648-653.

[156] Krikke, H. \& Van Der Laan, E. 2011. Last Time Buy and control policies with phase-out returns: A case study in plant control systems, International Journal of Production Research, vol. 49, no. 17, pp. 51835206.

[157] Bogh, M. B., Mikkelsen, H., \& Wøhlk, S. 2014. Collection of recyclables from cubes - A case study, SocioEconomic Planning Sciences, vol. 48, no. 2, pp. 127-134.

[158] Selviaridis, K., Matopoulos, A., Thomas Szamosi, L., \& Psychogios, A. 2016. Reverse resource exchanges in service supply chains: the case of returnable transport packaging, Supply Chain Management: An International Journal, vol. 21, no. 3, pp. 381-397.

[159] Batarfi, R., Jaber, M. Y., \& Aljazzar, S. M. 2017. A profit maximization for a reverse logistics dual-channel supply chain with a return policy, Computers and Industrial Engineering, vol. 106, pp. 58-82.

[160] Ashodian, J. 2016. Industry 4.0 Is Transforming Supply Chains. p. 7, https://scgmmh.s3.amazonaws.com/pdfs/sick_wp_industry4.0_100616.pdf.

[161] De Man, J. C. \& Strandhagen, J. O. 2017. An Industry 4.0 Research Agenda for Sustainable Business Models, Procedia CIRP, vol. 63, pp. 721-726. 